\title{
Proposed approaches to systematic planning of research and monitoring to support a South African inland fisheries policy
}

\author{
S Hugo'* (iD and OLF Weyl',2+ (iD \\ 'DSI/NRF Research Chair in Inland Fisheries and Freshwater Ecology, South African Institute for Aquatic Biodiversity, Makhanda, 6140, \\ South Africa \\ ${ }^{2}$ Department of Ichthyology and Fisheries Science, Rhodes University, Makhanda, 6140, South Africa \\ *Current affiliation: Department of Biological Sciences, Faculty of Science, Engineering and Agriculture, University of Venda, \\ University Road, Thohoyandou, 0950, South Africa \\ ${ }^{+}$Deceased
}

\begin{abstract}
A South African inland fisheries policy will depend on a reliable long-term supply of social-ecological data covering freshwater fisheries at a broad geographic scale. Approaches to systematic planning of research and monitoring are demonstrated herein, based on a fishery-independent gillnet dataset covering 44 dams, and geographic information system maps of monthly and annual climate variables, human land use, and road access in a $5 \mathrm{~km}$ zone around 442 dams. Generalised linear mixed models were used to determine the covariates of gillnet catch per unit effort. Such covariates are required for a model-based process to select a subset of state-owned dams for a long-term fishery survey programme. The models indicated a monthly climate influence on catch per unit effort and climatic drivers of fish species distributions. However, unexplained variation is overwhelming and precludes a model-based survey design process. Non-hierarchical clustering of 442 dams was then done based on annual climate and human land use variables around dams. The resulting clusters of dams with shared climate and land use characteristics indicates the types of dams that should be selected for monitoring to represent the full range of climate and land use characteristics. Surrounding land use could indicate the socioeconomic characteristics of fisheries, for example, dams that may support subsistence-based communities that require increased research effort. Finally, although primary catchments could be useful for organising national-scale management, land use cover in the $5 \mathrm{~km}$ zone around dams varied widely within the respective primary catchments. Beyond these proposed approaches to plan research, this study also reveals various data deficiencies and recommends additional future studies on other possible methods for systematic research planning.
\end{abstract}

\section{INTRODUCTION}

South African freshwater impoundments play an important role in food security and poverty alleviation, by housing fish populations that are valued for recreation and consumption (Ellender et al., 2009; Beard et al., 2011; McCafferty et al., 2012; Beatty et al., 2017). Large-scale commercial freshwater fisheries are generally economically unviable in South Africa (McCafferty et al., 2012; Britz, 2015; Barkhuizen et al., 2016). However, recreational fishing has been well-established for decades and contributes to local economies (Ellender et al., 2009; McCafferty et al., 2012; Britz, 2015). Small-scale and subsistence freshwater fisheries are widespread and increasing, but, due to historical marginalisation and lack of institutional policy support, often conflict with recreational fishers (Andrew et al., 2000; Hara and Backeberg, 2014; Britz, 2015; Tapela et al., 2015).

The need for an institutional policy for the sustainable management and equitable use of freshwater fisheries has been discussed in a series of papers (e.g. Weyl et al., 2007; McCafferty et al., 2012; Hara and Backeberg, 2014; Britz, 2015). These studies and others (e.g. Beard et al., 2011; Lynch et al., 2016; Weyl et al., 2021) highlight the need for capacity building in the small-scale fishing sector and preventing ecosystem degradation and overfishing that may be exacerbated by stakeholder conflicts. Since 2016 the Department of Environment, Forestry and Fisheries of South Africa has been developing the National Freshwater (Inland) Wild Capture Fisheries Policy following national and international sustainable development guidelines and the ecosystem approach to fisheries (Beard et al., 2011; Weyl et al., 2021). Policy development is supported by comprehensive social-ecological data collated in two Water Research Commission scoping studies (Britz et al., 2015; Tapela et al., 2015). Subsequently, in June 2018, the Southern African Society of Aquatic Scientists convened a workshop to identify priority research questions and knowledge requirements for the policy (Weyl et al., 2021).

Sustainable management in a national policy framework is dependent on data that can be readily supplied with simple methods at a reasonable cost (Bonar and Hubert, 2002; Walmsley, 2002). Currently the immediate knowledge requirements for policy development and implementation are impeded by a lack of recent or long-term data on fishery stocks and socioeconomic characteristics covering inland waterbodies across South Africa (McCafferty et al., 2012; Britz et al., 2015; Tapela et al., 2015; Weyl et al., 2021). Like inland fisheries worldwide, South African dams' ecological and socioeconomic characteristics vary spatiotemporally, which precludes blanket management and

\section{CORRESPONDENCE}

SHugo

EMAIL

sanet.hugo@univen.ac.za

\section{DATES}

Received: 10 September 2020

Accepted: 14 July 2021

\section{KEYWORDS}

classification analysis

fishery independent surveys

freshwater fishery

geographic information system recreational fishing

small-scale fishing

\section{COPYRIGHT}

(c) The Author(s)

Published under a Creative

Commons Attribution 4.0

International Licence

(CC BY 4.0) 
legislation and necessitates dam-specific adaptive management and data collection (Hara and Backeberg, 2014; Britz et al., 2015; Weyl et al., 2021). Thus, comprehensive multi-disciplinary information is needed for each dam, including the population and life-history characteristics of the target species, types of users (e.g. recreational, subsistence or commercial), harvest methods (e.g. gear type, intensity and frequency), and the economic and subsistence value (Weyl et al., 2007; Ellender et al., 2009; McCafferty et al., 2012; Hara and Backeberg, 2014; Britz, 2015).

Many rapid sampling methods can supply these data on a caseby-case basis (Beard et al., 2011; Tapela et al., 2015; Lorenzen et al., 2016). However, sustained long-term sampling is needed for adaptive management and to monitor effects from further socioeconomic development and climate change (Dallas and Rivers-Moore, 2014; Paukert et al., 2017; Kao et al., 2020). Consequently, cost and labour input may need to be systematically prioritised, focusing on fisheries that are most likely to be vulnerable to environmental stressors, generate reliable data, and support sustainable development goals (Beard et al., 2011; Hara and Backeberg, 2014; Paukert et al., 2017). Lack of funding and irregular data collection is pervasive on inland fisheries worldwide, and overcoming the resultant data deficiencies is an active area of research (Beard et al., 2011; Lorenzen et al., 2016; Lynch et al., 2016; Deines et al., 2017; Paukert et al., 2017). Some tools suggested by recent global-scale studies (e.g. Lorenzen et al., 2016; Deines et al., 2017; Kao et al., 2020) may be useful in a South African context, including using geographic information system (GIS) climate and land use data, and using representative subsets of waterbodies for modelling general patterns.

Fisheries-independent surveys (FIS) are widely regarded as a valuable element of fisheries management, given that the sampling method can be standardised for comparison across regions (Bonar and Hubert, 2002; McCafferty, 2012; Lorenzen et al., 2016). Although FIS can enable rapid stock assessment, such as assessing fish size distribution and community structure, its real value lies in supplying catch per unit effort (CPUE) in a long-term time-series to monitor how fish populations respond to changes in fishing pressure and the environment (Peel et al., 2012; Lorenzen et al., 2016). McCafferty (2012) modelled CPUE of 26 dams across South Africa based on a gillnet fleet with a matching range of mesh sizes (see also Weyl et al., 2007; Winker, 2010). This dataset, housed at the South African Institute for Aquatic Biodiversity, has since expanded to 44 dams representing several river basins and climate zones, and spanning the years 1998 to 2017 (personal observation, see methods section). However, too few recurrent samples from individual dams are available for a time-series.

To initiate a long-term monitoring programme, additions to the gillnet dataset can focus on recurrent sampling of a representative subset of dams across South Africa to produce reliable costeffective predictive estimates that can be extrapolated to poorly sampled or unsampled dams (Lorenzen et al., 2016). A representative subset of dams can be selected through a modelbased survey design process, which has pertinent advantages over a random stratified survey design process (Peel et al., 2012). Model-based design accommodates multiple target species with different habitat requirements, variable sampling effort due to logistical and practical constraints (e.g. different dam sizes and remote location of dams) and non-Gaussian response variables (McCafferty, 2012; Peel et al., 2012). However, model-based survey design depends strongly on predictive covariates - a substantial amount of initial data is required to determine the relationships between CPUE and covariates and build the initial model (Peel et al., 2012). McCafferty's (2012) models did not reveal strong covariate relationships, and therefore the utility of the expanded gillnet dataset for determining useful relationships needs to be evaluated before a model-based survey can be designed.

Given the current unavailability of a fishery monitoring programme, a large-scale spatial analysis linking dams to environmental variation and human activity indicators could identify dams with common social-ecological characteristics to prioritise for intensive multidisciplinary assessments (Beard et al., 2011; Camp et al., 2020). This approach is reminiscent of a conservation planning assessment, where high-biodiversity areas that are threatened by human activities are revealed for priority conservation actions under various cost and budget scenarios (e.g. Rivers-Moore et al., 2011). Britz et al. (2015) used GIS climate data and expert scores to identify river basins suitable for stocking with fishery species. However, there is a further need to quantify variation in human land use and climate, which may vary in their relative importance or have synergistic effects on fish populations (Dallas and Rivers-Moore, 2014; Camp et al., 2020; Jackson et al., 2020; Kao et al., 2020). An assessment of the characteristics of a large number of dams covering a large geographic area complements both random stratified and model-based survey design by evaluating the full range of variation in climatic and human-related covariates that need to be represented by selected sampling sites (Peel et al., 2012; Baker et al., 2019).

Dams often support a combination of recreational and subsistence fishing (Britz et al., 2015; Ellender et al., 2009; Tapela et al., 2015). Nevertheless, Weyl et al. (2007) suggest that common characteristics like access, potential for tourism, and dominant fish species, predispose dams to different management types, e.g., commercial, recreational, open access and community-managed subsistence fishing. Dams located in an area with low economic development (e.g., close to a rural town or subsistence farms) could be essential to local food security (Weyl et al., 2007; Britz et al., 2015; Tapela et al., 2015). Dams located in remote, sparsely populated and untransformed areas, or in nature reserves with restricted access, may have a higher value as a recreational fishery (Weyl et al., 2007; Britz et al., 2015). Dams enclosed in commercial agricultural property may have limited scope in terms of fishery development (Weyl et al., 2007; Britz et al., 2015).

In the current study, the utility of existing data from fisheryindependent gillnet surveys was examined in relation to climatic and human-related factors, with the aim to provide the background information needed to design a long-term modelbased monitoring programme. Further, a broad range of dams across South Africa is classified based on spatially associated climatic and human-related characteristics, to explore whether such broad-scale classification could enable setting data collection and management goals. Both these objectives focused on the local area surrounding each dam following Ellender et al. (2009), who emphasized the local interactions between the Gariep Dam and both subsistence and recreational fishers. However, dams likely influence and are influenced by a larger surrounding region (e.g. a river drainage basin or primary catchment, Walmsley, 2002; Jooste et al., 2014; Jackson et al., 2020). Therefore, the current study also examined the available data in relation to South Africa's primary catchments, specifically whether land use characteristics surrounding dams are comparable to general conditions in the catchments and, consequently, whether catchments are useful units within which to organise fishery management.

\section{METHODS}

\section{Gillnet data}

Between the years 1998 and 2017, 44 dams were sampled with a standard fleet of gillnets comprising five randomly positioned panels, with stretched mesh sizes of $44 \mathrm{~mm}, 60 \mathrm{~mm}, 70 \mathrm{~mm}$, 
$100 \mathrm{~mm}$ and $144 \mathrm{~mm}$ ( $9 \mathrm{~m} \mathrm{x} 3 \mathrm{~m}$ panels, total size $45 \mathrm{~m} \times 3 \mathrm{~m}$ ), and the data stored at the South African Institute for Aquatic Biodiversity. Dams were sampled within different years and months, many dams were sampled only once, and effort (number of nets deployed) varied among dams and months. Six species that are most widespread in this dataset were examined: common carp (Cyprinus carpio, 31 dams), African sharp-toothed catfish (Clarias gariepinus, 35 dams), Mozambique tilapia (Oreochromis mossambicus, 14 dams), smallmouth yellowfish (Labeobarbus aeneus, 21 dams), moggel (Labeo umbratus, 28 dams), and Orange River mudfish (Labeo capensis, 21 dams). Catch per unit effort (CPUE) of all species summed was also examined and CPUE of all native cyprinids, i.e., the sum of L. aeneus, L. umbratus, L. capensis, papermouth (Enteromius mattozi), largemouth yellowfish (Labeobarbus kimberleyensis), largescale yellowfish (Labeobarbus marequensis), leaden labeo (Labeo molybdinus) and rednose labeo (Labeo rosae).

\section{Geographic information system data}

A GIS map of 435 dam polygons (DWA, 2011) was used to represent a broad range of the larger dams and lakes ( $>2$ ha surface area) present within all the river basins delineated in the primary catchments of South Africa (DWA, 2009). Seven dams for which gillnet data were available were not present in the GIS dams map. Therefore, the surface water land class from the South African National Landcover database (DEA, 2015) was used to create polygons at the dams' coordinates in QGIS version 3.6.2 (QGIS Development Team, 2018) and added to the larger map, for a total of 442 dams (Fig. 1). Next, QGIS was used to calculate the surface area of each dam from the polygons, and a buffer zone of $5 \mathrm{~km}$ was delineated around each dam. Then, QGIS was used to calculate road density (CD:NGI, 1998) as length per unit area $\left(\mathrm{km}\right.$ per $\left.\mathrm{km}^{2}\right)$ in the buffer zones, and $\mathrm{R}$ ( $\mathrm{R}$ core team, 2018) geographic packages 'raster' (Hijmans, 2019) and 'rgdal' (Bivand et al., 2018) were used to quantify mean values of the climatic variables, and percentage cover of the land use variables and protected area in the buffer zones. Climatic variables included annual mean temperature, minimum temperature of the coldest month (hereafter 'minimum temperature'), maximum temperature of the warmest month (hereafter 'maximum temperature') and annual precipitation for all 442 dams, as well as mean monthly temperature and precipitation matching the gillnet monthly data (Hijmans et al., 2005). Land use variables included percentage cover of commercial and subsistence cultivated area, percentage formal urban build-up (cities and towns) and rural build-up (villages) and the percentage natural (untransformed) area (DEA, 2015). Protected area was a combination of formal national parks, provincial reserves, and private game reserves (SANParks, 2004).

\section{Analyses}

The relationship between monthly gillnet CPUE for each dam, and climatic variables, land use types, road density, protected area and dam area, was examined using generalised linear mixed effects models (R package 'lme4', Bates et al., 2015) with the dams' identities as random effect. Number of nets deployed per month per dam was used as an offset term to account for variation in sampling effort, which ensures that CPUE is modelled when catch weight is the response variable (Shono, 2008). Further, the data were weighted by sampling year to reduce the importance of older data that might not be a reasonable representation of recent or current fish population size, and likely do not match the fairly new land use dataset. Total CPUE was modelled with a gamma distribution for positive continuous data, whereas CPUE of native cyprinids and each of the six dominant species were modelled with the Tweedie distribution for positive continuous data with zeros (R package 'mgcv', Tweedie, 1984; Shono, 2008; Peel et al., 2012).

To find the most parsimonious combination of predictor variables that best explain each response variable, redundant variables were removed by evaluating collinearity (variance inflation factors from the R package 'car', Fox and Weisberg, 2019), and then applying a backwards stepwise selection procedure to find the model with the lowest Akaike's Information Criterion value. The outcome of each of these best-fitting models were expressed as an analysis of variance (ANOVA), where the random effect's test statistic and significance were obtained by comparing a model without the random effect to the model with the random effect ( $\mathrm{R}$ function 'anova'). Finally, to compare dams, CPUE was estimated for each dam from each 'best' model, but where the

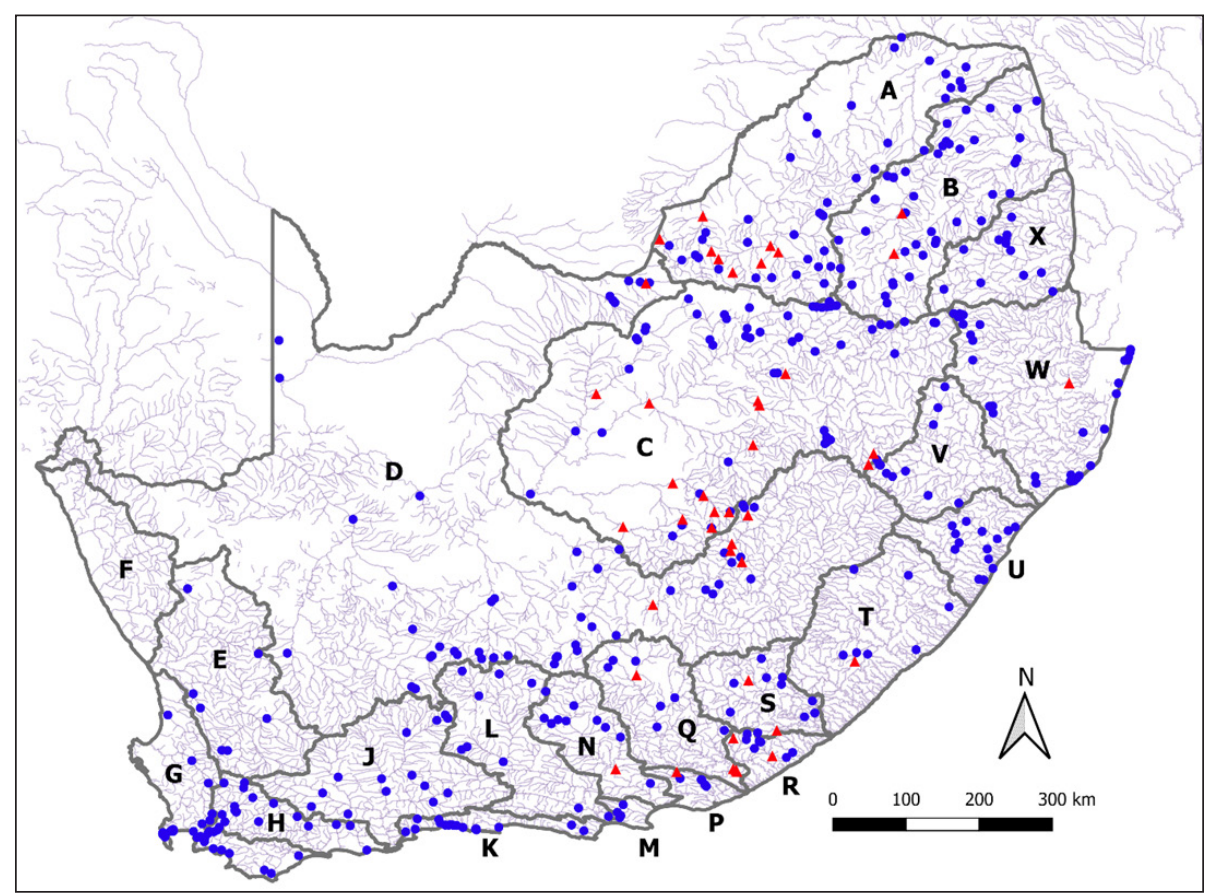

Figure 1. A representative set of 442 dams across South Africa, with triangles indicating the 44 dams with gillnet data. The river basins delineated by primary catchments are indicated with the standard alphabetic codes, with faint lines depicting the river network. 
monthly mean temperature and precipitation was kept at a constant (mean values across the dataset) to remove any seasonal effects ('predict.lme' from R package 'nlme', Pinheiro et al., 2018).

Next, all 442 dams were classified: firstly, according to the four climatic variables (annual mean, minimum and maximum temperature and annual precipitation) and, secondly, according to the four human land use types, natural (untransformed) land cover, protected area cover, and road density. Classification was done through first conducting a principal component analysis (PCA), and then using the scores of the first components that together explain more than $80 \%$ of variation to conduct a k-means cluster analysis limited to four clusters for simplicity (R Core Team, 2018).

Finally, percentage cover of the four human land use types was calculated for each primary catchment (Bivand et al., 2018; Hijmans, 2019). Variation among dams in terms of percentage land use cover within the $5 \mathrm{~km}$ buffer zones was illustrated with violin plots (R package 'yarrr', Phillips, 2017) grouped by primary catchment (DWAS, 2009). Wilcoxon rank sum tests, the non-parametric equivalent to 1 -sample $t$-tests, were used to test whether this variation was significant. Specifically, the difference between land use around dams and land use in the whole catchment was calculated, and the Wilcoxon test was used to compare these differences to a mean of zero. The test was only applied when more than 5 non-zero values were available. A Holm correction was applied to the multiple $p$ values obtained from catchments for each land cover type (Holm, 1979).

\section{RESULTS}

\section{Gillnet data analysis}

Natural land cover was collinear with human land use cover (negatively related), and annual mean temperature was collinear with minimum and maximum temperature, and these two variables were therefore not included in models (variance inflation factors for remaining variables < 4.5). Dam surface area was not included in any models after backwards stepwise selection.

Generally, CPUE increased in warmer months and decreased in wetter months, except for C. carpio, O. mossambicus and L. capensis (Table 1). Total CPUE has a weak negative relationship with minimum temperature and native cyprinid CPUE models did not include any climate covariates other than monthly temperature and monthly precipitation, likely because species with different climate associations are combined. CPUE for individual species indicate climate affiliations (Appendix, Fig. A1) - most species were negatively related to minimum and maximum temperatures and annual precipitation, except for the positive relationships between
O. mossambicus and minimum and maximum temperature and annual precipitation, and between C. gariepinus and maximum temperature (Table 1).

Human land use variables had much weaker relationships with CPUE, and were included in fewer models. Native cyprinid CPUE was negatively related to both types of urban build-up. C. gariepinus was negatively related to rural build-up and road density, O. mossambicus positively related to protected area and formal urban build-up and negatively related to road density, and L. aeneus and $L$. umbratus were positively related to commercial cultivation (Table 1).

The random effect had the strongest influence in all models, indicating large variation among dams that are not accounted for by the variables examined in the current study (Table 1). Further, some total CPUE estimates are much lower than CPUE estimates for specific species (e.g., L. aeneus in Armenia and Sterkfontein Dams). Additionally, although the Tweedie models successfully estimated zero CPUE where positive samples were absent, some of these estimates are associated with very high uncertainty (Appendix, Table A1).

\section{Cluster analysis}

The first two components of the PCA on the four climatic variables explain more than $86 \%$ variation, with highest factor loadings by annual mean temperature and minimum temperature in Component 1, and highest loadings of maximum temperature and annual precipitation in Component 2 (Appendix, Table A2). Therefore, the k-means cluster analysis was conducted on the first two components. The four clusters illustrate fairly clear climate zones (Fig. 2A, Table 2): (1) low winter temperatures and low precipitation in the interior north-west of the escarpment, (2) high temperatures overall and high precipitation along the eastern coast and north-east, (3) milder temperatures and high precipitation south along the coast and east of the escarpment, (4) high summer temperatures and low precipitation in the north and west.

The first four components of the land use PCA represent more than $81 \%$ of the variation (Appendix, Table A3) and were used for k-means clustering. These clusters appear more geographically scattered compared to the climatic clusters; however, they have clear characteristics that were also reflected in the associations among variables in the factor loadings (Fig. 2B, Table 3 and Table A3): (1) high protected area and untransformed land cover, (2) high road density and formal urban build-up indicating major cities like Cape Town, Johannesburg and Pretoria, (3) high commercial cultivation cover, and (4) high subsistence cultivation and rural build-up.

Table 1. Analysis of variance output from general linear mixed models with dam as random effect, to examine the relationship between CPUE and climatic and human-related variables. The chi-square test statistics are presented, together with the level of significance depicted symbolically to distinguish between positive and negative linear relationships, where relevant

\begin{tabular}{|c|c|c|c|c|c|c|c|c|}
\hline & Total & Cyprinids & C. carpio & C.gariepinus & O.mossambicus & L.aeneus & L. capensis & L. umbratus \\
\hline Monthly temperature $\left({ }^{\circ} \mathrm{C}\right)$ & $9.4^{* *}$ & $14.8^{* * *}$ & n.i. & $55.6^{* * * *}$ & $8.0^{* *}$ & $110.9^{* * * *}$ & 40.6†十†† & $8.3^{* *}$ \\
\hline Monthly precipitation (mm) & $12.0 \dagger+†$ & 11.0††† & n.i. & 91.9†††† & $5.5^{*}$ & 72.2†††† & n.i. & $7.7+\dagger$ \\
\hline Minimum temperature $\left({ }^{\circ} \mathrm{C}\right)$ & $8.1+\dagger$ & n.i. & 11.9††† & $14.9+† \dagger$ & $4.4^{*}$ & 9.9†† & $36.2 †+† \dagger$ & n.i. \\
\hline Maximum temperature $\left({ }^{\circ} \mathrm{C}\right)$ & n.i. & n.i. & n.i. & $16.6^{* * * *}$ & $7.1^{* *}$ & 24.8†††† & $8.9+\dagger$ & 17.6†††† \\
\hline Annual precipitation (mm) & n.i. & n.i. & n.i. & n.i. & $4.2^{*}$ & 20.3†††† & 17.7†††† & $15.4 †+\dagger$ \\
\hline Protected area (\%) & n.i. & n.i. & n.i. & n.i. & $6.1^{*}$ & n.i. & n.i. & n.i. \\
\hline Commercial cultivation (\%) & n.i. & n.i. & n.i. & n.i. & n.i. & $6.9 * *$ & n.i. & $14.9 * * *$ \\
\hline Formal urban (\%) & n.i. & $3.9+$ & n.i. & n.i. & $9.5^{* *}$ & n.i. & n.i. & n.i. \\
\hline Rural urban (\%) & n.i. & $4.5+$ & n.i. & $10.4 \uparrow \dagger$ & n.i & n.i & n.i. & n.i. \\
\hline Road density $\left(\mathrm{km} \cdot \mathrm{km}^{-2}\right)$ & n.i. & n.i & n.i. & $4.8+$ & $9.6+†$ & n.i. & n.i. & n.i. \\
\hline Dam identity & $1530.1^{* * * *}$ & $2008.9^{* * * *}$ & $976.66^{* * * *}$ & $1183.7^{* * * *}$ & $1226.6^{* * * *}$ & $960.18^{* * * *}$ & $708.7^{* * * *}$ & $1969.0^{* * * *}$ \\
\hline
\end{tabular}

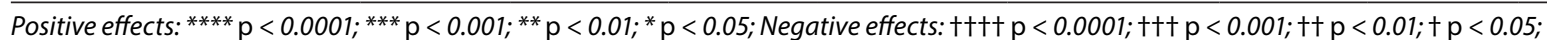

n.i. $=$ Not included in model with best fit 
Table 2. The mean and standard deviation of climatic variables in each of the four climatic k-means clusters obtained from the first two components of a PCA

\begin{tabular}{lcccc}
\hline & Cluster 1 & Cluster 2 & Cluster 3 & Cluster 4 \\
\hline Annual mean temperature $\left({ }^{\circ} \mathrm{C}\right)$ & $15.6 \pm 1.1$ & $20.4 \pm 1.4$ & $16.2 \pm 1.1$ & $19.2 \pm 1.4$ \\
Minimum temperature $\left({ }^{\circ} \mathrm{C}\right)$ & $-0.4 \pm 2.1$ & $10.0 \pm 2.3$ & $5.1 \pm 2.7$ & $4.1 \pm 2.0$ \\
Maximum temperature $\left({ }^{\circ} \mathrm{C}\right)$ & $29.8 \pm 1.6$ & $30.2 \pm 1.4$ & $26.8 \pm 1.6$ & $32.6 \pm 1.7$ \\
Annual precipitation $(\mathrm{mm})$ & $476.8 \pm 163.5$ & $925.5 \pm 164.6$ & $717.1 \pm 137.8$ & $493.4 \pm 153.1$ \\
\hline
\end{tabular}

Table 3. The mean and standard deviation of percentage coverage of land use and protected area and road density, in each of the four land use k-means clusters obtained from the first four components of a PCA

\begin{tabular}{|c|c|c|c|c|}
\hline & Cluster 1 & Cluster 2 & Cluster 3 & Cluster 4 \\
\hline Protected area (\%) & $12.0 \pm 20.0$ & $3.1 \pm 5.6$ & $3.4 \pm 6.0$ & $3.5 \pm 11.4$ \\
\hline Natural (\%) & $80.2 \pm 14.3$ & $38.6 \pm 11.4$ & $46.7 \pm 16.1$ & $61.1 \pm 13.1$ \\
\hline Commercial cultivation (\%) & $5.2 \pm 5.9$ & $4.2 \pm 3.2$ & $25.8 \pm 18.2$ & $1.9 \pm 3.3$ \\
\hline Subsistence cultivation (\%) & $0.6 \pm 1.8$ & $0.04 \pm 0.1$ & $0.3 \pm 1.0$ & $12.8 \pm 8.7$ \\
\hline Formal urban build-up (\%) & $0.8 \pm 2.2$ & $25.2 \pm 9.8$ & $2.0 \pm 3.2$ & $0.5 \pm 1.1$ \\
\hline Rural build-up (\%) & $1.0 \pm 2.5$ & $0.01 \pm 0.01$ & $1.0 \pm 2.8$ & $15.3 \pm 10.7$ \\
\hline Road density $\left(\mathrm{km} \cdot \mathrm{km}^{-2}\right)$ & $2.7 \pm 1.0$ & $7.4 \pm 3.0$ & $3.6 \pm 1.2$ & $3.5 \pm 1.3$ \\
\hline
\end{tabular}

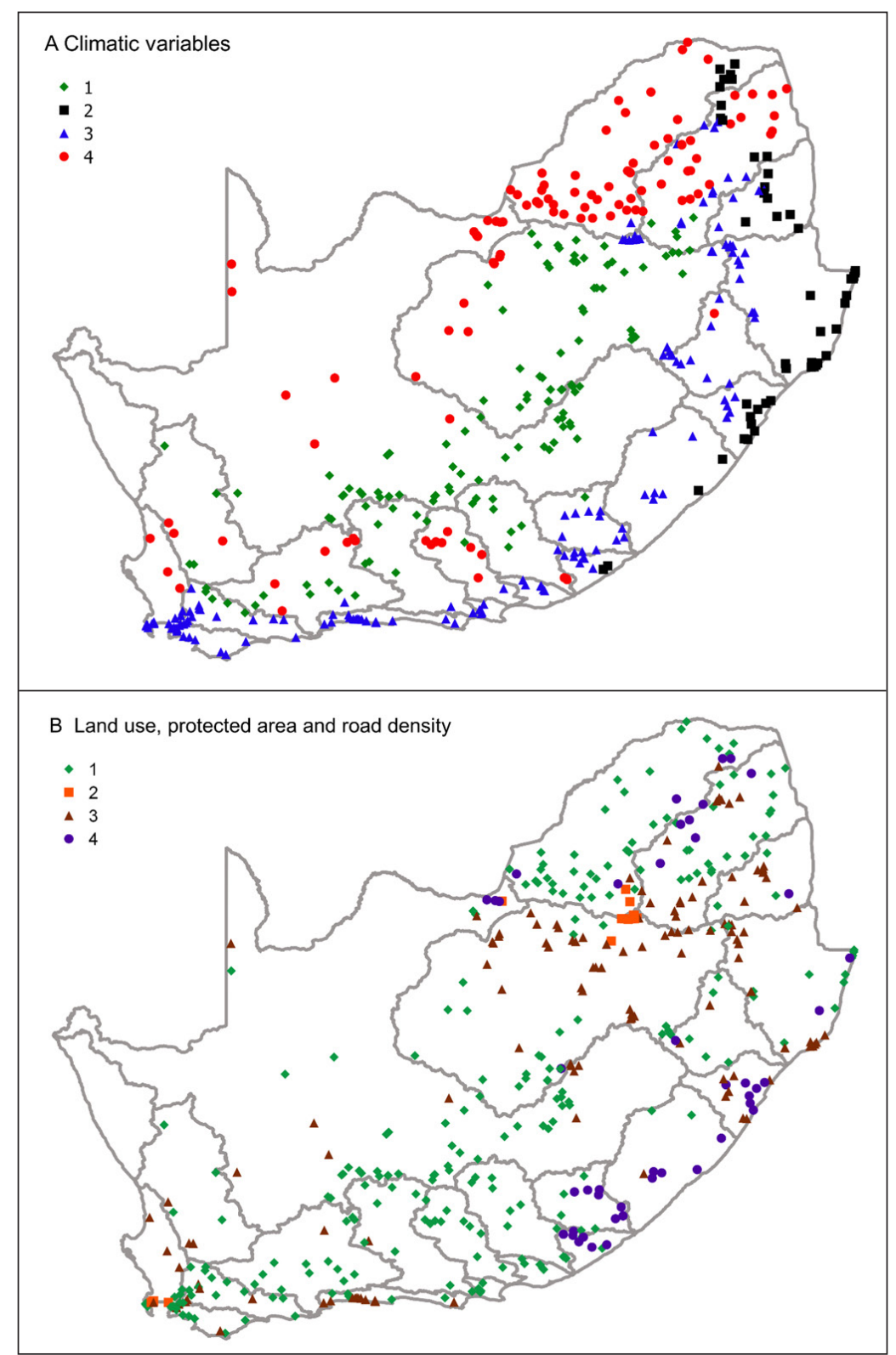

Figure 2. Principal component analyses and k-means cluster analyses produced groups of dams with (A) shared climatic characteristics summarised in Table 2 and (B) shared human-related characteristics summarised in Table 3 


\section{Comparison with land use in primary catchments}

Catchments C, D, E, G, H, J, K, L, M, N, P and Q were covered by less than $1 \%$ of subsistence cultivation and rural build-up (Fig. 3, Appendix: Table A4). Only catchments G, K, M, R and $\mathrm{U}$ were covered by more than $1 \%$ cover of formal urban buildup (Fig. 3, Table A4). Commercial agriculture was present in all catchments (minimum $1.36 \%$ cover, Fig. 3, Table A4). Land use cover in the $5 \mathrm{~km}$ zone around dams varied widely for all catchments (Fig. 3). Where a Wilcoxon rank sum test was applied this variation was significantly different from the land cover in the whole catchments (Fig. 3, Table A4).

\section{DISCUSSION}

A South African inland fisheries policy and related adaptive management objectives will depend on a reliable long-term supply of social-ecological data covering fisheries at a broad geographic scale, which would require developing a sustainable data collection programme (Britz et al., 2015; Tapela et al., 2015; Lynch et al., 2016; Weyl et al., 2021). The current study explored the use of easily obtainable existing data from dams across South Africa to systematically plan research and monitoring, following similar approaches demonstrated in previous global-scale studies (Lorenzen et al., 2016; Deines et al., 2017; Kao et al., 2020). Based on available fishery-independent gillnet data and GIS climatic and land use data, the study revealed the variation in fish CPUE, climate and land use among dams across South Africa, as well as data deficiencies where increased research is urgently needed.
The findings could contribute to prioritisation of fisheries for further intensive research to meet policy knowledge requirements and initialise a long-term monitoring programme (Weyl et al., 2020).

Fishery-independent gillnet CPUE was generally found to vary with monthly temperature and precipitation, likely due to seasonal variation in fish abundance and catchability, which should be taken into account in future fishery-independent surveys (Pope and Willis, 1996). Further, variation in CPUE indicates the climatic associations of species distributions, e.g., $O$. mossambicus and C. gariepinus in warmer climates and L. aeneus and L. capensis in cooler climates (Appendix: Fig. A1). Longterm monitoring could reveal negative or positive responses to global warming, depending on precipitation patterns and species' thermal tolerances (Dallas and Rivers-Moore, 2014; Paukert et al., 2017; Jackson et al., 2020; Kao et al., 2020). Although dam surface area is likely to be important in practice, e.g., due to variation in total fish population size, dam area was not included in any models and is likely unimportant when selecting dams for a longterm monitoring programme. CPUE was generally weakly related to protected area, road density and human land use. Possible reasons are that gillnet-sampled dams are generally not associated with high values of human land use (more on this later), and that the effects may be positive or negative depending on the dam and therefore only detectable over long-term sampling (Camp et al., 2020; Kao et al., 2020). Other ecological community measures may also be better indicators of human impacts (e.g., functional diversity: Jackson et al., 2020).

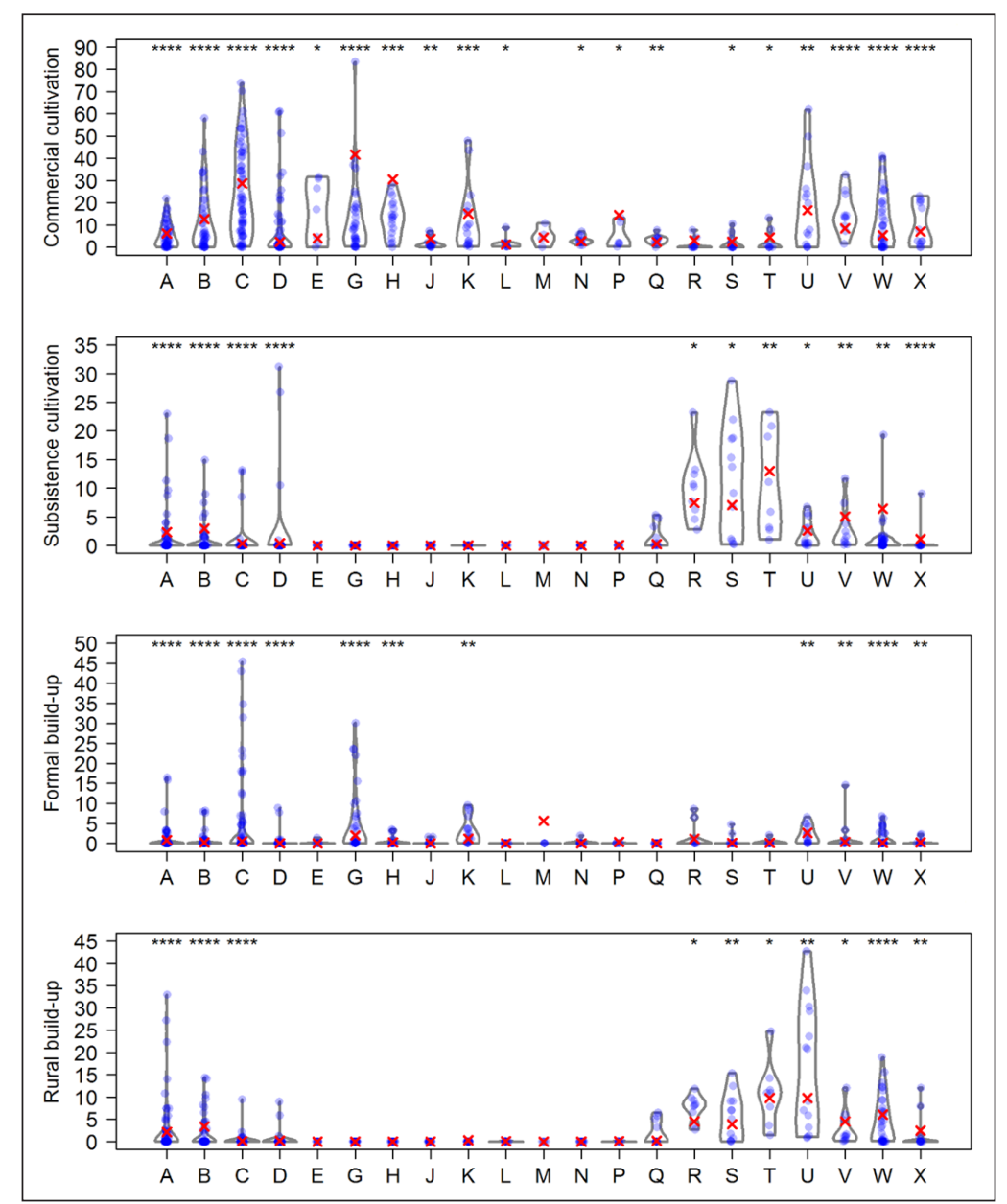

Figure 3. Violin and point density plots show the variation among dams in terms of percent coverage in the $5 \mathrm{~km}$ zone around each dam in commercial cultivation, subsistence cultivation, formal urban build-up and rural build-up, grouped by primary catchment indicated by standard alphabetic codes. Crosses are the percent coverage of the land use type in each catchment. Asterisks indicate Holm-corrected $p$ values from Wilcoxon rank sum tests indicating that land use around dams are significantly different from percentage cover in the whole catchment: ${ }^{*}<0.05$, ${ }^{* *}<0.001,{ }^{* * *}<0.001,{ }^{* * * *}<0.0001$. Where asterisks are absent, data were too few for a test. 
Despite ecologically meaningful relationships between CPUE and monthly and annual climate, the current FIS gillnet dataset is insufficient to generalise to unsampled dams and inform a modelbased survey design. All significant relationships with CPUE were weak compared to the large unexplained variation among dams (Table 1), and there are too few data to test possible overfitting. Additionally, high uncertainty exists for many of the CPUE estimates, possibly due to insufficient repeated samples or stations (e.g. Tyefu Dam with only one sample: Appendix, Table A1), or insufficient coverage of the climatic range relevant to the species (e.g. O. mossambicus, Table A1, Fig. A1). Other options for planning large-scale monitoring include random stratified site selection, and using statistical methods like integrated assessment modelling to combine data from different sources, e.g., combining FIS and fishery-dependent survey (FDS) data (Lorenzen et al., 2016; Deines et al., 2017; Kao et al., 2020). Additionally, FDS data like records from recreational or subsistence fishing may be better for monitoring species that are not sampled well with gillnets, like common carp Cyprinus carpio and largemouth bass Micropterus salmoides (Winker, 2010; McCafferty, 2012).

The large-scale classification approach may be useful in the absence of, or during the early development stages of, a long-term fishery monitoring dataset, by revealing high-value or high-risk dams to prioritise for intensive data collection. The current study revealed groups of dams with shared climatic characteristics that seem to associate with certain primary catchments due to the strong effect of the escarpment (Figs 1 and 2A). Although the gillnet models cannot generalise CPUE estimates to unsampled dams, these climate clusters roughly indicate dams where certain fish species could thrive, or dams where fish populations should be monitored for vulnerability to climate change (Britz et al., 2015; Jackson et al., 2020; Kao et al., 2020). Dominant species' CPUE estimates broadly match the climate clusters, with comparatively higher CPUE for L. aeneus and L. capensis associated with the relatively cooler Cluster 1 , whereas $O$. mossambicus are largely present in Cluster 4 where maximum temperature is higher (Table 2, Fig. 2A and Appendix: Fig. A1). Dams in Cluster 2 (high temperature and high rainfall) are currently represented by only three dams with gillnet data, which could bias predictions of fish species distributions.

Groups of dams with shared human-related characteristics are geographically more scattered (Fig. 2B); however, they have very distinct characteristics, signifying (1) dams in remote untransformed and protected areas, (2) dams close to towns and cities, (3) dams surrounded by commercial cultivation, and (4) dams close to rural communities depending on subsistence cultivation (Table 3). Clusters 1 and 4 may be suitable targets for recreational fishery management and small-scale fishery development, respectively, depending on the population size of the dominant fish species (Weyl et al., 2007). Of the 44 gillnetsampled dams, 32 are associated with Cluster 1, and dams characterised by more substantial transformed land cover are currently very poorly represented. Of the 6 gillnet-sampled dams associated with Cluster 4, only Dimbaza dam is estimated to have a fairly high L. umbratus CPUE (Appendix, Table A1). More fishery data is needed from dams associated with subsistence communities through additional gillnet samples, or by obtaining catch size records from the local fishers (see e.g. Appendix 1 in Tapela et al., 2015).

The current study focused on a $5 \mathrm{~km}$ zone around each individual dam to better represent access. However, the influence of human activities and climate on waterbodies is often examined at a catchment level, as dam-specific data are often scarce, and aquatic ecosystems are influenced by human activities and climate in whole river drainage basins (Jooste et al., 2014; Jackson et al.,
2020; Kao et al., 2020). The South African primary catchments have distinct combinations of human land use cover generally indicating the types of communities and dams that are present (Fig. 3) and suggesting that primary catchments might be useful units for organising sustainable management (Walmsley, 2002). However, as shown in the current study, a general assessment of the catchment might not reflect conditions specific to dams as there is substantial variation among dams within catchments in terms of land use cover in the $5 \mathrm{~km}$ zone.

Although the gillnet data were not sufficient to study the effect of human activities, and human-related and climate characteristics were not combined to classify dams, the influence of human activities and environmental variation may be synergistic (Paukert et al., 2017; Jackson et al., 2020; Kao et al., 2020). For example, clean water supply could increase the resilience of aquatic ecosystems to a changing climate and increased human activities (Dallas and Rivers-Moore, 2014; Kao et al., 2020). However, precipitation is projected to decrease, especially in the southwestern winter rainfall region of South Africa, with a general increase in rainfall intensity and extreme flood or drought events compounding the stresses from agricultural intensification and urban expansion on aquatic ecosystems (Dallas and RiversMoore et al., 2014; Archer et al., 2018; Jackson et al., 2020). Dams are increasingly important as refuges for fish during droughts, while competing with human water consumption (Beatty et al., 2017). Sustainable economic development is much needed in socioeconomically underdeveloped areas, and could ensure increased water use efficiency and quality, and sanitation access to reduce pollution (Kao et al., 2020). However, unsustainable human land use intensification or poorly planned development could affect aquatic ecosystems through increased erosion, sedimentation, eutrophication and heavy metal pollution, and decrease fish population resilience and fishery product quality and safety, possibly further marginalising those most dependent on the fishery (Papu-Zamxaka et al., 2010; Jooste et al., 2014; Jackson et al., 2020; Kao et al., 2020). This further highlights the need to study the social-ecological dynamics of fisheries and incorporate human activity, social and economic data into fishery survey and monitoring programmes (Beard et al., 2011; Hara and Backeberg, 2014; Tapela et al., 2015).

\section{CONCLUSIONS}

The current study demonstrates how available data, like the FIS gillnet data and GIS data evaluated here, could be used to streamline the development of a sustainable data collection programme for a South African inland fisheries policy, while also revealing data gaps where increased research should be focused. Broad-scale classification of dams by climate and land use associations is a method for rapidly prioritising dams for further dam-specific data collection. Dam-specific research should include assessing fishery potential and current fishing activity, and identifying dams that are unsuitable for fishing (e.g. polluted dams), thereby further refining the selection of dams for fishery management and monitoring (Papu-Zamxaka et al., 2010; Jooste et al., 2014; Weyl et al. 2021). The classification analysis identified dams that are likely important for small-scale and subsistence fisheries, which require increased research effort (Hara and Backeberg, 2014; Tapela et al., 2015). However, dam-specific research may identify many dams with mixed recreational, subsistence and small-scale fisheries that require support for multiple stakeholders (Smith et al., 2005; Ellender et al., 2009; Weyl et al. 2021).

Before the FIS gillnet dataset would be useful for modelling general patterns or model-based sampling design, it should be expanded with recurrent samples from dams representing the full range of climate and land use characteristics indicated by 
the classification analyses. Further, the predictive capability of models could be improved by consistently recording additional variables that influence CPUE, other than seasonal climate. For example, fish abundance could be affected by fishing pressure, whereas catchability could be affected by turbidity, water temperature and time of day (Vašek et al., 2009; Latour, 2016; Weyl et al., 2021). Other possible methods to obtain CPUE data should also be examined, including random stratified survey design and combining catch data from various sources, including fishery-dependent data (Paukert et al., 2017; Camp et al., 2020). Moreover, long-term monitoring can be iteratively improved by periodically revising the survey design and sampling methods according to data insufficiencies revealed by models based on previously collected data (Guisan et al., 2006). Therefore, the cost and effort spent to develop and maintain a long-term monitoring programme will return increasingly valuable data that are essential for adaptive management responses to environmental and socioeconomic change.

\section{ACKNOWLEDGEMENTS}

The helpful comments from two anonymous reviewers were very much appreciated. This study was supported by the infrastructure provided by the SAIAB Research Platform and the funding channelled through the NRF-SAIAB Institutional Support system as well as support from the National Research Foundation - South African Research Chairs Initiative of the Department of Science and Innovation (Grant No. 110507) and the NRF Professional Development Programme (Grant No. 104911). Any opinion, finding and conclusion or recommendation expressed in this material is that of the authors and the NRF do not accept any liability in this regard.

\section{AUTHOR CONTRIBUTIONS}

SH conceptualised the study and developed the methodology, analysed and interpreted the data and wrote the initial draft. OLFW supplied the gillnet data, contributed to the study concept and edited the manuscript.

\section{ORCID}

S Hugo

https://orcid.org/0000-0001-8636-3985

OLF Weyl

https://orcid.org/0000-0002-8935-3296

\section{REFERENCES}

ANDREW TG, ROUHANI QA and SETI SJ (2000) Can small-scale fisheries contribute to poverty alleviation in traditionally nonfishing communities in South Africa? Afr. J. Aquat. Sci. 25 (1) 50-55. https://doi.org/10.2989/160859100780177938

ARCHER E, ENGELBRECHT F, HÄNSLER A, LANDMAN W, TADROSS M and HELMSCHROT J (2018) Seasonal prediction and regional climate projections for southern Africa. In: Revermann R, Krewenka KM, Schmiedel U, Olwoch JM, Helmschrot J and Jürgens N (eds.) Climate Change and Adaptive Land Management in Southern Africa - Assessments, Changes, Challenges, and Solutions. Klaus Hess Publishers, Göttingen \& Windhoek. https://doi.org/ 10.7809/b-e.00296

BAKER MR, PALSSON W, ZIMMERMAN $M$ and ROOPER CN (2019) Model of trawlable area using benthic terrain and oceanographic variables-Informing survey design and habitat maps in the Gulf of Alaska. Fish. Oceanogr. 28 (6) 629-657. https:// doi.org/10.1111/fog.12442

BARKHUIZEN LM, WEYL OLF and VAN AS JG (2016) A qualitative and quantitative analysis of historic commercial fisheries in the Free State Province in South Africa. Water SA. 42 (4) 601-605. https:// doi.org/10.4314/wsa.v42i4.10
BATES B, MAECHLER M, BOLKER B and WALKER S (2015) Fitting linear mixed-effects models using lme4. J. Stat. Softw. 67 (1) 1-48. https://doi.org/10.18637/jss.v067.i01

BEARD TD, ARLINHAUS R, COOKE SJ, MCINTYRE PB, DE SILVA S, BARTLEY D and COWX IG (2011) Ecosystem approach to inland fisheries: research needs and implementation strategies. Biol. Letters. 7 (4) 481-483. https://doi.org/10.1098/rsbl.2011.0046

BEATTY S, ALLEN M, LYMBERY A, JORDAAN MS, MORGAN D, IMPSON D, MARR S, EBNER B and WEYL OLF (2017) Rethinking refuges: Implications of climate change for dam busting. Biol. Conserv. 209 188-195. https://doi.org/10.1016/j.biocon.2017.02.007

BIVAND R, KEITT T and ROWLINGSON B (2018) rgdal: Bindings for the 'Geospatial' Data Abstraction Library. R package version 1.3-6.

BONAR SA and HUBERT WA (2002) Standard sampling of inland fish: benefits, challenges, and a call for action. Fisheries. 27 10-16. https:// doi.org/10.1577/1548-8446(2002)027<0010:ssoif>2.0.co;2

BRITZ P (2015) The history of South African inland fisheries policy with governance recommendations for the democratic era. Water SA. 41 (5) 624-632. https://doi.org/10.4314/wsa.v41i5.05

BRITZ PJ, HARA MM, WEYL OLF, TAPELA BN and ROUHANI QA (2015) Scoping study on the development and sustainable utilisation of inland fisheries in South Africa Volume 1: Research report. WRC Report No. TT 615/1/14. Water Research Commission, Pretoria.

CAMP EV, KAEMING MA, AHRENS RNM, POTTS WM, PINE WE, WEYL OLF and POPE KL (2020) Resilience management for conservation of inland recreational fisheries. Front. Ecol. Evol. 7 498. https://doi.org/10.3389/fevo.2019.00498

CD:NGI (1998) Roads: 1:500 000 Topographical Edition of South Africa. Chief Directorate: National Geo-Spatial Information, Department of Agriculture, Rural Development and Land Reform. http://daffarcgis.nda.agric.za/portal/home/

DALLAS HF and RIVERS-MOORE N (2014) Ecological consequences of global climate change for freshwater ecosystems in South Africa. S. Afr. J. Sci. 110 (5-6) 1-11. https://doi.org/10.1590/sajs.2014/20130274

DEA (Department of Environmental Affairs, South Africa) (2015) South African National Land Cover, Department of Environmental Affairs, Pretoria. https://egis.environment.gov.za/data_egis/data_ download/current

DEINES AM, BUNNELL DB, ROGERS MW, BENNION D, WOELMER W, SAYERS MJ, GRIMM AG, SHUCHMAN RA, RAYMER ZB, BROOKS CN, MYCHEK-LONDER JG, TAYLOR W and BEARD TD (2017) The contribution of lakes to global inland fisheries harvest. Front. Ecol. Environ. 15 (6) 293-298. https://doi. org/10.1002/fee.1503

DWA (Department of Water Affairs, South Africa) (2009) Catchments of South Africa. Department of Water Affairs, Pretoria. https://doi. org/10.15493/SARVA.DWS.10000003

DWA (Department of Water Affairs, South Africa) (2011) Dams and lakes, electronic dataset. Department of Water Affairs, Pretoria. https://doi.org/10.15493/SARVA.DWS.10000001

ELLENDER BR, WEYL OLF and WINKER H (2009) Who uses the fishery resources in South Africa's largest impoundment? Characterising subsistence and recreational fishing sectors on Lake Gariep. Water SA. 35 (5) 677-682. https://doi.org/10.4314/wsa.v35i5.49194

FOX J and WEISBERG S (2019) An R Companion to Applied Regression ( $3^{\text {rd }}$ edn). Sage Publications, Thousand Oaks CA.

GUISAN A, BROENNIMANN O, ENGLER R, VUST M, YOCCOZ NG, LEHMANN A and ZIMMERMANN NE (2005) Using niche-based models to improve the sampling of rare species. Conserv. Biol. 20 (2) 501-511. https://doi.org/10.1111/j.1523-1739.2006.00354.x

HARA MM and BACKEBERG GR (2014) An institutional approach for developing South African inland freshwater fisheries for improved food security and rural livelihoods. Water SA. 40 (2) 277-286. https://doi.org/10.4314/wsa.v40i2.10

HIJMANS RJ, CAMERON SE, PARRA JL, JONES PG and JARVIS A (2005) Very high resolution interpolated climate surfaces for global land areas. Int. J. Climatol. 25 (15) 1965-1978. https://doi. org/10.1002/joc.1276

HIJMANS RJ (2019) raster: Geographic Data Analysis and Modeling. $\mathrm{R}$ package version 2.8-19.

HOLM S (1979) A simple sequentially rejective multiple test procedure. Scand. J. Stat. 6 65-70. 
JACKSON MC, FOURIE HE, DALUT, WOODFORD DJ, WASSERMAN RJ, ZENGEYA TA, ELLENDER BR, KIMBERG PK, JORDAAN MS, CHIMIMBA CT and WEYL OLF (2020) Food web properties vary with climate and land use in South African streams. Funct. Ecol. 34 (8) 1653-1665. https://doi.org/10.1111/1365-2435.13601

JOOSTE A, MARR SM, ADDO-BEDIAKO A and LUUS-POWELI WJ (2014) Metal bioaccumulation in the fish of the Olifants River, Limpopo province, South Africa, and the associated human health risk: a case study of rednose labeo Labeo rosae from two impoundments. Afr. J. Aquat. Sci. 39 (3) 271-277. https://doi.org/10. 2989/16085914.2014.945989

KAO Y, ROGERS MW, BUNNELL DB, COWX IG, QIAN SS, ANNEVILLE O, BEARD TD, BRINKER A, BRITTON JR, CHURA-CRUZ R and co-authors (2020) Effects of climate and land-use changes on fish catches across lakes at a global scale. Nat. Commun. 11 2526. https://doi.org/10.1038/s41467-020-14624-2

LATOUR RJ (2016) Explaining patterns of pelagic fish abundance in the Sacramento-San Joaquin Delta. Estuaries Coast. 39 233-247. https:// doi.org/10.1007/s12237-015-9968-9

LORENZEN K, COWX LG, ENTSUA-MENSAH REM, LESTER NP, KOEHN JD, RANDALL RG, SO N, BONAR SA, BUNNELL DB, VENTURELLI P, BOWER SD and COOKE SJ (2016) Stock assessment in inland fisheries: a foundation for sustainable use and conservation. Rev. Fish Biol. Fisher. 26 405-440. https://doi. org/10.1007/s11160-016-9435-0

LYNCH AJ, COOKE SJ, DEINES AM, BOWER SD, BUNNEL DB, COWX IG, NGUYEN VM, NOHNER J, PHOUTHAVONG K, RILEY B, ROGERS MW, TAYLOR WW, WOELMER W, YOUN S and BEARD TD (2016) The social, economic, and environmental importance of inland fisheries. Environ. Rev. 24 (2) 115-121. https:// doi.org/10.1139/er-2015-0064

MCCAFFERTY JR (2012) An assessment of inland fisheries in South Africa using fisheries-dependent and fisheries-independent data sources. PhD thesis, Rhodes University.

MCCAFFERTY JR, ELLENDER BR, WEYL OLF and BRITZ PJ (2012) The use of water resources for inland fisheries in South Africa. Water SA. 38 (2) 327-344. https://doi.org/10.4314/wsa.v38i2.18

PAPU-ZAMXAKA V, MATHEE A, HARPHAM T, BARNES B, RÖLLIN H, LYONS M, JORDAAN W and CLOETE M (2010) Elevated mercury exposure in communities living alongside the Inanda Dam, South Africa. J. Environ. Monitor. 12 (2) 472-477. https://doi.org/10.1039/b917452d

PAUKERT CP, LYNCH AJ, BEARD TD, YUSHUN C, COOKE SJ, COOPERMAN MS, COWX IG, IBENGWE L, INFANTE DM, MYERS BJE, HÒA PHÚ N and WINFIELD IJ (2017) Designing a global assessment of climate change on inland fish and fisheries: knowns and needs. Rev. Fish Biol. Fisher. 27 (2) 393-409. https://doi. org/10.1007/s11160-017-9477-y

PEEL D, BRAVINGTON MV, KELLY N, WOOD SN and KNUCKEY I (2012) A model-based approach to designing a fishery-independent survey. J. Agr. Biol. Envir. St. 18 (1) 1-21. https://doi.org/10.1007/ s13253-012-0114-x

PHILLIPS N (2017) yarrr: a companion to the e-book "YaRrr!: The pirate's guide to $\mathrm{R}$ ”. R package version 0.1.5.
PINHEIRO J, BATES D, DEBROY S, SARKAR D and R CORE TEAM (2018) nlme: Linear and nonlinear mixed effects models. R package version 3.1-137.

POPE KL and WILLIS DW (1996) Seasonal influences on freshwater fisheries sampling data. Rev. Fish. Sci. 4 (1) 57-73. https://doi. org/10.1080/10641269609388578

QGIS DEVELOPMENT TEAM (2018) QGIS Geographic Information System. Open Source Geospatial Foundation Project. URL: http:// qgis.osgeo.org

R CORE TEAM (2018) R: A language and environment for statistical computing. R Foundation for Statistical Computing, Vienna, Austria. https://www.R-project.org/

RIVERS-MOORE NA, GOODMAN PS and NEL JL (2011) Scale-based freshwater conservation planning: towards protecting freshwater biodiversity in KwaZulu-Natal, South Africa. Freshwater Biol. 56 125-141. https://doi.org/10.1111/j.1365-2427.2010.02387.x

SANPARKS (2004) Archived NSBA Terrestrial Protected Areas vector geospatial dataset. South African National Parks, Pretoria. URL: http://bgis.sanbi.org/SpatialDataset/Detail/150

SHONO H (2008) Application of the Tweedie distribution to zerocatch data in CPUE analysis. Fish. Res. 93 (1-2) 154-162. https://doi. org/10.1016/j.fishres.2008.03.006

SMITH LED, KHOA N and LORENZEN K (2005) Livelihood function of inland fisheries: policy implications in developing countries. Water Policy. 7 (4) 359-383. https://doi.org/10.2166/wp.2005.0023

TAPELA BN, BRITZ PJ and ROUHANI QA (2015) Scoping study on the development and sustainable utilisation of inland fisheries in South Africa Volume 2: Case studies of small-scale inland fisheries. WRC Report No. TT 615/2/14. Water Research Commission, Pretoria.

TWEEDIE MCK (1984) An index which distinguishes between some important exponential families. In: Ghosh JK and Roy J (eds.) Statistics: Applications and New Directions. Proceedings of the Indian Statistical Institute Golden Jubilee International Conference. Indian Statistical Institute, Calcutta.

VAŠEKA M, KUBEČKA J, ČECH M, DRAŠTIK V, MATĔNA J, MRKVIČKA T, PETERKA J and PRCHALOVÁ M (2009) Diel variation in gillnet catches and vertical distribution of pelagic fishes in a stratified European reservoir. Fish. Res. 96 64-69. https://doi. org/10.1016/j.fishres.2008.09.010

WALMSLEY JJ (2002) Framework for measuring sustainable development in catchment systems. Environ. Manage. 29 195-206. https:// doi.org/10.1007/s00267-001-0020-4

WEYL OLF, BARKHUIZEN L, CHRISTISON K, DALU T, HLUNGWANI HA, IMPSON D, SANKAR K, MANDRAK NE, MARR SM, SARA JR and co-authors (2021) Ten research questions to support South Africa's Inland Fisheries Policy. Afr. J. Aquat. Sci. 46 (1) 1-10. https://doi.org/10.2989/16085914.2020.1822774

WEYL OLF, POTTS W, ROUHANI QA and BRITZ P (2007) The need for inland fisheries policy in South Africa: a case study of the North West Province. Water SA. 33 (4) 497-504.

WINKER H (2010) Post-impoundment population dynamics of nonnative common carp Cyprinus carpio in relation to two large native cyprinids in Lake Gariep, South Africa. PhD thesis, Rhodes University. 


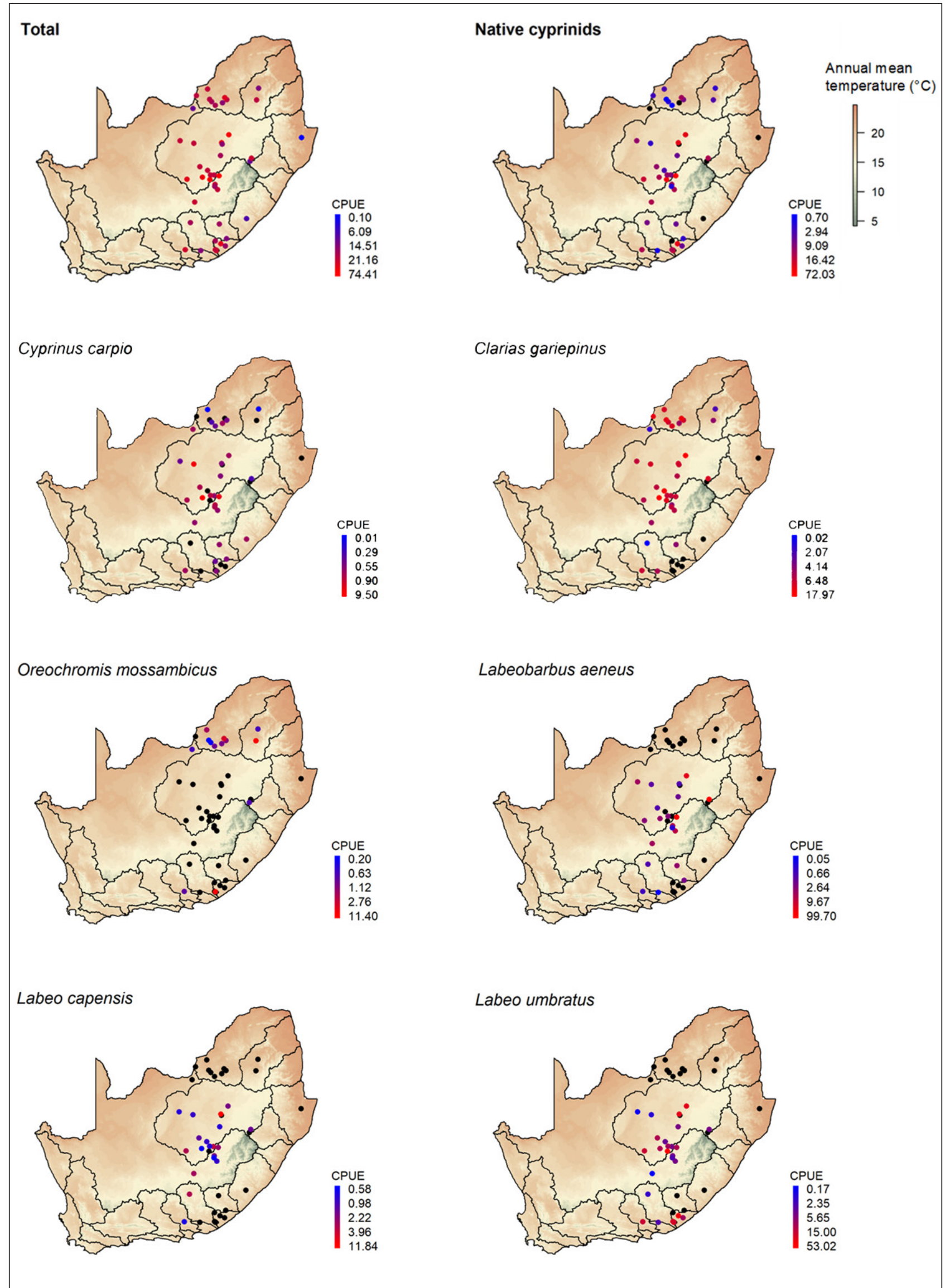

Figure A1. The location of the dams listed in Table A1, with CPUE ( $\mathrm{kg} \cdot \mathrm{month}^{-1} \cdot \mathrm{sampling} \mathrm{station}^{-1}$ ) estimates indicated and primary catchments delineated. The CPUE colour scales are on the logarithmic scale to better distinguish visually, with black indicating zero 
Table A1. The predicted catch per unit effort (CPUE, $\mathrm{kg} \cdot \mathrm{month}^{-1} \cdot$ sampling station $\left.^{-1}\right)$ from each dam derived from models presented in Table 1 in the main text, where monthly temperature and precipitation were kept constant (at mean value across dataset). Lower and upper bounds of the $95 \%$ confidence intervals are in brackets

\begin{tabular}{|c|c|c|c|c|c|c|c|c|}
\hline $\begin{array}{l}\text { Catchment } \\
\text { and dam }\end{array}$ & Total & $\begin{array}{l}\text { Native } \\
\text { cyprinids }\end{array}$ & $\begin{array}{l}\text { Cyprinus } \\
\text { carpio }\end{array}$ & $\begin{array}{c}\text { Clarias } \\
\text { gariepinus }\end{array}$ & $\begin{array}{l}\text { Oreochromis } \\
\text { mossambicus }\end{array}$ & $\begin{array}{c}\text { Labeobarbus } \\
\text { aeneus }\end{array}$ & $\begin{array}{l}\text { Labeo } \\
\text { capensis }\end{array}$ & $\begin{array}{l}\text { Labeo } \\
\text { umbratus }\end{array}$ \\
\hline A Bospoort & $\begin{array}{c}4.05 \\
(2.08 ; 7.88)\end{array}$ & $\begin{array}{c}0.00 \\
(0.00 ; 0.00)\end{array}$ & $\begin{array}{c}0.69 \\
(0.22 ; 2.15)\end{array}$ & $\begin{array}{c}1.39 \\
(0.48 ; 4.00)\end{array}$ & $\begin{array}{c}1.47 \\
(0.81 ; 2.64)\end{array}$ & $\begin{array}{c}0.00 \\
(0.00 ; 3.99)\end{array}$ & $\begin{array}{c}0.00 \\
(0.00 ; 0.48)\end{array}$ & $\begin{array}{c}0.00 \\
(0.00 ;>95.00)\end{array}$ \\
\hline A Koster & $\begin{array}{c}8.50 \\
(4.37 ; 16.54)\end{array}$ & $\begin{array}{c}0.70 \\
(0.24 ; 1.98)\end{array}$ & $\begin{array}{c}0.21 \\
(0.05 ; 0.98)\end{array}$ & $\begin{array}{c}6.48 \\
(3.06 ; 13.71)\end{array}$ & $\begin{array}{c}1.12 \\
(0.57 ; 2.20)\end{array}$ & $\begin{array}{c}0.00 \\
(0.00 ; 0.40)\end{array}$ & $\begin{array}{c}0.00 \\
(0.00 ; 0.30)\end{array}$ & $\begin{array}{c}0.00 \\
(0.00 ;>95.00)\end{array}$ \\
\hline A Lindleyspoort & $\begin{array}{c}6.83 \\
(3.87 ; 12.05)\end{array}$ & $\begin{array}{c}1.46 \\
(0.67 ; 3.19)\end{array}$ & $\begin{array}{c}0.10 \\
(0.02 ; 0.46)\end{array}$ & $\begin{array}{c}5.09 \\
(2.60 ; 9.96)\end{array}$ & $\begin{array}{c}0.25 \\
(0.11 ; 0.59)\end{array}$ & $\begin{array}{c}0.00 \\
(0.00 ; 0.69)\end{array}$ & $\begin{array}{c}0.00 \\
(0.00 ; 0.27)\end{array}$ & $\begin{array}{c}0.00 \\
(0.00 ;>95.00)\end{array}$ \\
\hline A Madikwe & $\begin{array}{c}11.71 \\
(6.64 ; 20.65)\end{array}$ & $\begin{array}{c}1.05 \\
(0.46 ; 2.39)\end{array}$ & $\begin{array}{c}0.00 \\
(0.00 ; 0.60)\end{array}$ & $\begin{array}{c}9.01 \\
(5.20 ; 15.63)\end{array}$ & $\begin{array}{c}0.20 \\
(0.08 ; 0.52)\end{array}$ & $\begin{array}{c}0.00 \\
(0.00 ; 1.82)\end{array}$ & $\begin{array}{c}0.00 \\
(0.00 ; 0.19)\end{array}$ & $\begin{array}{c}0.00 \\
(0.00 ;>95.00)\end{array}$ \\
\hline A Molatedi & $\begin{array}{c}14.51 \\
(8.22 ; 25.59)\end{array}$ & $\begin{array}{c}3.37 \\
(1.75 ; 6.50)\end{array}$ & $\begin{array}{c}0.01 \\
(0.00 ; 0.11)\end{array}$ & $\begin{array}{c}5.29 \\
(3.03 ; 9.23)\end{array}$ & $\begin{array}{c}2.76 \\
(1.95 ; 3.89)\end{array}$ & $\begin{array}{c}0.00 \\
(0.00 ; 2.09)\end{array}$ & $\begin{array}{c}0.00 \\
(0.00 ; 0.20)\end{array}$ & $\begin{array}{c}0.00 \\
(0.00 ;>95.00)\end{array}$ \\
\hline A Ngotwane & $\begin{array}{c}14.21 \\
(8.06 ; 25.07)\end{array}$ & $\begin{array}{c}2.27 \\
(1.09 ; 4.72)\end{array}$ & $\begin{array}{c}0.00 \\
(0.00 ; 0.59)\end{array}$ & $\begin{array}{c}9.45 \\
(5.53 ; 16.14)\end{array}$ & $\begin{array}{c}0.00 \\
(0.00 ; 13.82)\end{array}$ & $\begin{array}{c}0.00 \\
(0.00 ; 0.05)\end{array}$ & $\begin{array}{c}0.00 \\
(0.00 ; 0.02)\end{array}$ & $\begin{array}{c}0.00 \\
(0.00 ; 33.47)\end{array}$ \\
\hline A Roodekopjes & $\begin{array}{c}14.08 \\
(7.98 ; 24.83)\end{array}$ & $\begin{array}{c}6.13 \\
(3.34 ; 11.27)\end{array}$ & $\begin{array}{c}0.29 \\
(0.09 ; 0.88)\end{array}$ & $\begin{array}{c}4.83 \\
(2.63 ; 8.86)\end{array}$ & $\begin{array}{c}1.75 \\
(1.16 ; 2.64)\end{array}$ & $\begin{array}{c}0.00 \\
(0.00 ; 1.30)\end{array}$ & $\begin{array}{c}0.00 \\
(0.00 ; 0.23)\end{array}$ & $\begin{array}{c}0.00 \\
(0.00 ; 94.12)\end{array}$ \\
\hline A Vaalkop & $\begin{array}{c}29.39 \\
(16.66 ; 51.84)\end{array}$ & $\begin{array}{c}11.93 \\
(6.74 ; 21.13)\end{array}$ & $\begin{array}{c}0.00 \\
(0.00 ; 0.57)\end{array}$ & $\begin{array}{c}10.12 \\
(5.91 ; 17.36)\end{array}$ & $\begin{array}{c}5.41 \\
(4.02 ; 7.28)\end{array}$ & $\begin{array}{c}0.00 \\
(0.00 ; 3.14)\end{array}$ & $\begin{array}{c}0.00 \\
(0.00 ; 0.31)\end{array}$ & $\begin{array}{c}0.00 \\
(0.00 ;>95.00)\end{array}$ \\
\hline B Flag Boshielo & $\begin{array}{c}3.15 \\
(2.56 ; 3.88)\end{array}$ & $\begin{array}{c}1.98 \\
(1.53 ; 2.57)\end{array}$ & $\begin{array}{c}0.01 \\
(0.01 ; 0.03)\end{array}$ & $\begin{array}{c}0.15 \\
(0.09 ; 0.25)\end{array}$ & $\begin{array}{c}0.63 \\
(0.50 ; 0.78)\end{array}$ & $\begin{array}{c}0.00 \\
(0.00 ; 0.00)\end{array}$ & $\begin{array}{c}0.00 \\
(0.00 ; 0.00)\end{array}$ & $\begin{array}{c}0.00 \\
(0.00 ; 0.64)\end{array}$ \\
\hline B Loskop & $\begin{array}{c}12.50 \\
(6.64 ; 23.54)\end{array}$ & $\begin{array}{c}2.94 \\
(1.56 ; 5.53)\end{array}$ & $\begin{array}{c}0.00 \\
(0.00 ; 0.30)\end{array}$ & $\begin{array}{c}1.00 \\
(0.51 ; 1.95)\end{array}$ & $\begin{array}{c}10.33 \\
(8.57 ; 12.45)\end{array}$ & $\begin{array}{c}0.00 \\
(0.00 ; 0.08)\end{array}$ & $\begin{array}{c}0.00 \\
(0.00 ; 0.01)\end{array}$ & $\begin{array}{c}0.00 \\
(0.00 ; 12.47)\end{array}$ \\
\hline C Allemanskraal & $\begin{array}{c}7.72 \\
(3.74 ; 15.97)\end{array}$ & $\begin{array}{c}4.75 \\
(2.23 ; 10.10)\end{array}$ & $\begin{array}{c}0.41 \\
(0.13 ; 1.28)\end{array}$ & $\begin{array}{c}2.67 \\
(1.13 ; 6.34)\end{array}$ & $\begin{array}{c}0.00 \\
(0.00 ; 33.24)\end{array}$ & $\begin{array}{c}1.16 \\
(0.52 ; 2.61)\end{array}$ & $\begin{array}{c}0.92 \\
(0.44 ; 1.91)\end{array}$ & $\begin{array}{c}2.40 \\
(1.27 ; 4.54)\end{array}$ \\
\hline C Bloemhoek & $\begin{array}{c}42.66 \\
(20.63 ; 88.23)\end{array}$ & $\begin{array}{c}36.92 \\
(18.59 ; 73.35)\end{array}$ & $\begin{array}{c}0.43 \\
(0.09 ; 2.13)\end{array}$ & $\begin{array}{c}5.35 \\
(1.86 ; 15.40)\end{array}$ & $\begin{array}{c}0.00 \\
(0.00 ;>33.30)\end{array}$ & $\begin{array}{c}0.63 \\
(0.18 ; 2.23)\end{array}$ & $\begin{array}{c}11.84 \\
(6.60 ; 21.25)\end{array}$ & $\begin{array}{c}25.43 \\
(15.65 ; 41.33)\end{array}$ \\
\hline C Bloemhoff & $\begin{array}{c}15.12 \\
(7.31 ; 31.27)\end{array}$ & $\begin{array}{c}2.16 \\
(0.94 ; 5.00)\end{array}$ & $\begin{array}{c}6.13 \\
(3.43 ; 10.98)\end{array}$ & $\begin{array}{c}5.38 \\
(2.78 ; 10.43)\end{array}$ & $\begin{array}{c}0.00 \\
(0.00 ; 26.52)\end{array}$ & $\begin{array}{c}0.78 \\
(0.36 ; 1.69)\end{array}$ & $\begin{array}{c}1.11 \\
(0.54 ; 2.27)\end{array}$ & $\begin{array}{c}0.48 \\
(0.18 ; 1.28)\end{array}$ \\
\hline C Jimmy Roos & $\begin{array}{c}56.17 \\
(27.77 ; 113.61)\end{array}$ & $\begin{array}{c}51.02 \\
(27.23 ; 95.59)\end{array}$ & $\begin{array}{c}0.00 \\
(0.00 ; 1.63)\end{array}$ & $\begin{array}{c}7.12 \\
(2.93 ; 17.31)\end{array}$ & $\begin{array}{c}0.00 \\
(0.00 ;>33.30)\end{array}$ & $\begin{array}{c}0.00 \\
(0.00 ; 0.06)\end{array}$ & $\begin{array}{c}0.00 \\
(0.00 ; 0.02)\end{array}$ & $\begin{array}{c}53.02 \\
(37.02 ; 75.93)\end{array}$ \\
\hline C Kalkfontein & $\begin{array}{c}31.89 \\
(15.42 ; 65.94)\end{array}$ & $\begin{array}{c}27.67 \\
(15.76 ; 48.58)\end{array}$ & $\begin{array}{c}1.05 \\
(0.42 ; 2.59)\end{array}$ & $\begin{array}{c}2.07 \\
(0.98 ; 4.39)\end{array}$ & $\begin{array}{c}0.00 \\
(0.00 ;>33.30)\end{array}$ & $\begin{array}{c}2.64 \\
(1.57 ; 4.44)\end{array}$ & $\begin{array}{c}4.44 \\
(2.56 ; 7.67)\end{array}$ & $\begin{array}{c}15.00 \\
(10.83 ; 20.76)\end{array}$ \\
\hline C Koppies & $\begin{array}{c}53.40 \\
(25.82 ; 110.42)\end{array}$ & $\begin{array}{c}45.30 \\
(26.20 ; 78.34)\end{array}$ & $\begin{array}{c}0.78 \\
(0.29 ; 2.07)\end{array}$ & $\begin{array}{c}17.97 \\
(9.83 ; 32.84)\end{array}$ & $\begin{array}{c}0.00 \\
(0.00 ;>33.30)\end{array}$ & $\begin{array}{c}43.56 \\
(27.45 ; 69.12)\end{array}$ & $\begin{array}{c}2.40 \\
(1.31 ; 4.40)\end{array}$ & $\begin{array}{c}27.78 \\
(19.98 ; 38.61)\end{array}$ \\
\hline C Krugersdrift & $\begin{array}{c}15.68 \\
(9.40 ; 26.13)\end{array}$ & $\begin{array}{c}10.47 \\
(6.56 ; 16.72)\end{array}$ & $\begin{array}{c}1.21 \\
(0.65 ; 2.27)\end{array}$ & $\begin{array}{c}2.85 \\
(1.66 ; 4.90)\end{array}$ & $\begin{array}{c}0.00 \\
(0.00 ; 1.71)\end{array}$ & $\begin{array}{c}0.60 \\
(0.34 ; 1.05)\end{array}$ & $\begin{array}{c}1.77 \\
(1.11 ; 2.82)\end{array}$ & $\begin{array}{c}8.27 \\
(6.15 ; 11.11)\end{array}$ \\
\hline C Metsi Matso & $\begin{array}{c}1.64 \\
(0.81 ; 3.32)\end{array}$ & $\begin{array}{c}0.00 \\
(0.00 ; 0.01)\end{array}$ & $\begin{array}{c}0.00 \\
(0.00 ; 2.70)\end{array}$ & $\begin{array}{c}0.00 \\
(0.00 ; 7.69)\end{array}$ & $\begin{array}{c}0.79 \\
(0.34 ; 1.83)\end{array}$ & $\begin{array}{c}0.00 \\
(0.00 ; 1.75)\end{array}$ & $\begin{array}{c}0.00 \\
(0.00 ; 0.05)\end{array}$ & $\begin{array}{c}0.00 \\
(0.00 ;>95.00)\end{array}$ \\
\hline C Mockes & $\begin{array}{c}16.03 \\
(7.93 ; 32.43)\end{array}$ & $\begin{array}{c}3.07 \\
(1.18 ; 7.93)\end{array}$ & $\begin{array}{c}0.00 \\
(0.00 ; 1.86)\end{array}$ & $\begin{array}{c}11.63 \\
(5.45 ; 24.81)\end{array}$ & $\begin{array}{c}0.00 \\
(0.00 ;>33.30)\end{array}$ & $\begin{array}{c}0.00 \\
(0.00 ; 0.11)\end{array}$ & $\begin{array}{c}1.07 \\
(0.43 ; 2.69)\end{array}$ & $\begin{array}{c}2.25 \\
(0.90 ; 5.58)\end{array}$ \\
\hline C Moutloasi & $\begin{array}{c}12.59 \\
(7.56 ; 20.99)\end{array}$ & $\begin{array}{c}7.60 \\
(4.29 ; 13.45)\end{array}$ & $\begin{array}{c}0.54 \\
(0.21 ; 1.41)\end{array}$ & $\begin{array}{c}3.63 \\
(1.77 ; 7.44)\end{array}$ & $\begin{array}{c}0.00 \\
(0.00 ;>33.30)\end{array}$ & $\begin{array}{c}0.00 \\
(0.00 ; 0.02)\end{array}$ & $\begin{array}{c}5.51 \\
(3.57 ; 8.50)\end{array}$ & $\begin{array}{c}2.59 \\
(1.44 ; 4.64)\end{array}$ \\
\hline C Rustfontein & $\begin{array}{c}15.28 \\
(9.17 ; 25.48)\end{array}$ & $\begin{array}{c}9.09 \\
(5.61 ; 14.73)\end{array}$ & $\begin{array}{c}1.28 \\
(0.69 ; 2.37)\end{array}$ & $\begin{array}{c}4.14 \\
(2.45 ; 7.02)\end{array}$ & $\begin{array}{c}0.00 \\
(0.00 ;>33.30)\end{array}$ & $\begin{array}{c}2.25 \\
(1.41 ; 3.59)\end{array}$ & $\begin{array}{c}0.97 \\
(0.58 ; 1.64)\end{array}$ & $\begin{array}{c}5.48 \\
(3.87 ; 7.76)\end{array}$ \\
\hline C Serfontein & $\begin{array}{c}3.88 \\
(1.92 ; 7.86)\end{array}$ & $\begin{array}{c}0.00 \\
(0.00 ; 0.00)\end{array}$ & $\begin{array}{c}0.00 \\
(0.00 ; 2.11)\end{array}$ & $\begin{array}{c}4.65 \\
(1.61 ; 13.42)\end{array}$ & $\begin{array}{c}0.00 \\
(0.00 ;>33.30)\end{array}$ & $\begin{array}{c}0.00 \\
(0.00 ; 0.17)\end{array}$ & $\begin{array}{c}0.00 \\
(0.00 ; 0.04)\end{array}$ & $\begin{array}{c}0.00 \\
(0.00 ; 34.77)\end{array}$ \\
\hline C Sterkfontein & $\begin{array}{c}18.17 \\
(10.90 ; 30.29)\end{array}$ & $\begin{array}{c}16.42 \\
(10.28 ; 26.23)\end{array}$ & $\begin{array}{c}0.11 \\
(0.04 ; 0.35)\end{array}$ & $\begin{array}{c}6.50 \\
(3.26 ; 12.99)\end{array}$ & $\begin{array}{c}0.00 \\
(0.00 ; 9.05)\end{array}$ & $\begin{array}{c}99.70 \\
(68.95 ; 144.16)\end{array}$ & $\begin{array}{c}2.22 \\
(1.45 ; 3.39)\end{array}$ & $\begin{array}{c}2.91 \\
(1.71 ; 4.94)\end{array}$ \\
\hline C Taung & $\begin{array}{c}15.22 \\
(7.96 ; 29.10)\end{array}$ & $\begin{array}{c}11.08 \\
(5.83 ; 21.05)\end{array}$ & $\begin{array}{c}0.20 \\
(0.05 ; 0.84)\end{array}$ & $\begin{array}{c}3.39 \\
(1.57 ; 7.32)\end{array}$ & $\begin{array}{c}0.00 \\
(0.00 ;>33.30)\end{array}$ & $\begin{array}{c}6.37 \\
(3.84 ; 10.57)\end{array}$ & $\begin{array}{c}0.98 \\
(0.48 ; 2.04)\end{array}$ & $\begin{array}{c}0.27 \\
(0.08 ; 0.92)\end{array}$ \\
\hline C Tierpoort & $\begin{array}{c}43.33 \\
(21.42 ; 87.64)\end{array}$ & $\begin{array}{c}14.97 \\
(7.09 ; 31.58)\end{array}$ & $\begin{array}{c}9.50 \\
(4.65 ; 19.40)\end{array}$ & $\begin{array}{c}16.61 \\
(8.49 ; 32.50)\end{array}$ & $\begin{array}{c}0.00 \\
(0.00 ; 0.07)\end{array}$ & $\begin{array}{c}3.34 \\
(1.64 ; 6.83)\end{array}$ & $\begin{array}{c}0.70 \\
(0.26 ; 1.88)\end{array}$ & $\begin{array}{c}9.34 \\
(5.23 ; 16.68)\end{array}$ \\
\hline D Armenia & $\begin{array}{c}74.41 \\
(36.79 ; 150.51)\end{array}$ & $\begin{array}{c}72.03 \\
(39.36 ; 131.81)\end{array}$ & $\begin{array}{c}3.96 \\
(1.63 ; 9.63)\end{array}$ & $\begin{array}{c}3.92 \\
(1.26 ; 12.15)\end{array}$ & $\begin{array}{c}0.00 \\
(0.00 ;>33.30)\end{array}$ & $\begin{array}{c}91.63 \\
(57.83 ; 145.19)\end{array}$ & $\begin{array}{c}3.49 \\
(1.71 ; 7.10)\end{array}$ & $\begin{array}{c}7.11 \\
(3.55 ; 14.26)\end{array}$ \\
\hline D Egmont & $\begin{array}{c}16.30 \\
(9.78 ; 27.18)\end{array}$ & $\begin{array}{c}15.05 \\
(9.32 ; 24.30)\end{array}$ & $\begin{array}{c}0.55 \\
(0.24 ; 1.27)\end{array}$ & $\begin{array}{c}2.51 \\
(1.25 ; 5.01)\end{array}$ & $\begin{array}{c}0.00 \\
(0.00 ;>33.30)\end{array}$ & $\begin{array}{c}13.11 \\
(8.95 ; 19.21)\end{array}$ & $\begin{array}{c}1.07 \\
(0.62 ; 1.85)\end{array}$ & $\begin{array}{c}2.35 \\
(1.41 ; 3.94)\end{array}$ \\
\hline D Gariep & $\begin{array}{c}16.81 \\
(12.13 ; 23.29)\end{array}$ & $\begin{array}{c}14.62 \\
(11.17 ; 19.14)\end{array}$ & $\begin{array}{c}0.53 \\
(0.34 ; 0.82)\end{array}$ & $\begin{array}{c}1.38 \\
(0.93 ; 2.03)\end{array}$ & $\begin{array}{c}0.00 \\
(0.00 ; 5.29)\end{array}$ & $\begin{array}{c}5.84 \\
(4.72 ; 7.23)\end{array}$ & $\begin{array}{c}3.96 \\
(3.20 ; 4.91)\end{array}$ & $\begin{array}{c}0.17 \\
(0.10 ; 0.28)\end{array}$ \\
\hline
\end{tabular}


Table A1 Continued. The predicted catch per unit effort (CPUE, $\mathrm{kg} \cdot \mathrm{month}^{-1}$.sampling station ${ }^{-1}$ ) from each dam derived from models presented in Table 1 in the main text, where monthly temperature and precipitation were kept constant (at mean value across dataset). Lower and upper bounds of the $95 \%$ confidence intervals are in brackets

\begin{tabular}{|c|c|c|c|c|c|c|c|c|}
\hline $\begin{array}{l}\text { Catchment } \\
\text { and dam }\end{array}$ & Total & $\begin{array}{c}\text { Native } \\
\text { cyprinids }\end{array}$ & $\begin{array}{c}\text { Cyprinus } \\
\text { carpio }\end{array}$ & $\begin{array}{c}\text { Clarias } \\
\text { gariepinus }\end{array}$ & $\begin{array}{l}\text { Oreochromis } \\
\text { mossambicus }\end{array}$ & $\begin{array}{c}\text { Labeobarbus } \\
\text { aeneus }\end{array}$ & $\begin{array}{c}\text { Labeo } \\
\text { capensis }\end{array}$ & $\begin{array}{c}\text { Labeo } \\
\text { umbratus }\end{array}$ \\
\hline D Knellpoort & $\begin{array}{c}15.65 \\
(7.57 ; 32.37)\end{array}$ & $\begin{array}{c}12.76 \\
(6.67 ; 24.43)\end{array}$ & $\begin{array}{c}1.39 \\
(0.60 ; 3.22)\end{array}$ & $\begin{array}{c}0.73 \\
(0.23 ; 2.32)\end{array}$ & $\begin{array}{c}0.00 \\
(0.00 ;>33.30)\end{array}$ & $\begin{array}{c}9.67 \\
(5.83 ; 16.05)\end{array}$ & $\begin{array}{c}2.56 \\
(1.41 ; 4.64)\end{array}$ & $\begin{array}{c}2.59 \\
(1.41 ; 4.77)\end{array}$ \\
\hline D Lotlamoreng & $\begin{array}{c}1.70 \\
(0.89 ; 3.25)\end{array}$ & $\begin{array}{c}0.00 \\
(0.00 ; 0.00)\end{array}$ & $\begin{array}{c}0.84 \\
(0.23 ; 3.04)\end{array}$ & $\begin{array}{c}0.09 \\
(0.01 ; 1.14)\end{array}$ & $\begin{array}{c}0.55 \\
(0.20 ; 1.48)\end{array}$ & $\begin{array}{c}0.00 \\
(0.00 ; 13.52)\end{array}$ & $\begin{array}{c}0.00 \\
(0.00 ; 0.74)\end{array}$ & $\begin{array}{c}0.00 \\
(0.00 ;>95.00)\end{array}$ \\
\hline D Welbedacht & $\begin{array}{c}6.09 \\
(2.95 ; 12.60)\end{array}$ & $\begin{array}{c}1.64 \\
(0.55 ; 4.86)\end{array}$ & $\begin{array}{c}0.90 \\
(0.24 ; 3.41)\end{array}$ & $\begin{array}{c}3.45 \\
(1.13 ; 10.50)\end{array}$ & $\begin{array}{c}0.00 \\
(0.00 ;>33.30)\end{array}$ & $\begin{array}{c}0.20 \\
(0.05 ; 0.85)\end{array}$ & $\begin{array}{c}0.58 \\
(0.20 ; 1.68)\end{array}$ & $\begin{array}{c}1.00 \\
(0.29 ; 3.44)\end{array}$ \\
\hline K Binfield & $\begin{array}{c}7.21 \\
(3.40 ; 15.28)\end{array}$ & $\begin{array}{c}0.00 \\
(0.00 ; 0.00)\end{array}$ & $\begin{array}{c}0.21 \\
(0.06 ; 0.73)\end{array}$ & $\begin{array}{c}0.00 \\
(0.00 ; 1.14)\end{array}$ & $\begin{array}{c}0.00 \\
(0.00 ; 0.39)\end{array}$ & $\begin{array}{c}0.00 \\
(0.00 ; 0.02)\end{array}$ & $\begin{array}{c}0.00 \\
(0.00 ; 0.13)\end{array}$ & $\begin{array}{c}0.00 \\
(0.00 ; 2.80)\end{array}$ \\
\hline N Darlington & $\begin{array}{c}21.16 \\
(13.07 ; 34.25)\end{array}$ & $\begin{array}{c}17.21 \\
(11.16 ; 26.54)\end{array}$ & $\begin{array}{c}0.69 \\
(0.33 ; 1.43)\end{array}$ & $\begin{array}{c}4.38 \\
(2.67 ; 7.20)\end{array}$ & $\begin{array}{c}0.85 \\
(0.51 ; 1.41)\end{array}$ & $\begin{array}{c}0.46 \\
(0.26 ; 0.81)\end{array}$ & $\begin{array}{c}0.83 \\
(0.50 ; 1.37)\end{array}$ & $\begin{array}{c}14.39 \\
(11.19 ; 18.51)\end{array}$ \\
\hline P Glen Melville & $\begin{array}{c}3.44 \\
(1.80 ; 6.58)\end{array}$ & $\begin{array}{c}1.27 \\
(0.48 ; 3.37)\end{array}$ & $\begin{array}{c}0.00 \\
(0.00 ; 5.37)\end{array}$ & $\begin{array}{c}1.91 \\
(0.67 ; 5.44)\end{array}$ & $\begin{array}{c}0.00 \\
(0.00 ;>33.30)\end{array}$ & $\begin{array}{c}0.05 \\
(0.01 ; 0.22)\end{array}$ & $\begin{array}{c}0.00 \\
(0.00 ; 0.06)\end{array}$ & $\begin{array}{c}1.12 \\
(0.43 ; 2.90)\end{array}$ \\
\hline Q Grassridge & $\begin{array}{c}7.21 \\
(3.40 ; 15.27)\end{array}$ & $\begin{array}{c}6.99 \\
(3.10 ; 15.79)\end{array}$ & $\begin{array}{c}0.00 \\
(0.00 ; 0.33)\end{array}$ & $\begin{array}{c}0.02 \\
(0.00 ; 0.53)\end{array}$ & $\begin{array}{c}0.00 \\
(0.00 ;>33.30)\end{array}$ & $\begin{array}{c}0.66 \\
(0.27 ; 1.66)\end{array}$ & $\begin{array}{c}4.55 \\
(2.50 ; 8.28)\end{array}$ & $\begin{array}{c}0.71 \\
(0.24 ; 2.11)\end{array}$ \\
\hline Q Mangazana & $\begin{array}{c}21.20 \\
(10.00 ; 44.91)\end{array}$ & $\begin{array}{c}11.18 \\
(5.01 ; 24.92)\end{array}$ & $\begin{array}{c}0.00 \\
(0.00 ; 17.34)\end{array}$ & $\begin{array}{c}0.00 \\
(0.00 ; 2.17)\end{array}$ & $\begin{array}{c}11.40 \\
(7.98 ; 16.29)\end{array}$ & $\begin{array}{c}0.00 \\
(0.00 ; 0.79)\end{array}$ & $\begin{array}{c}0.00 \\
(0.00 ; 0.00)\end{array}$ & $\begin{array}{c}10.56 \\
(6.10 ; 18.26)\end{array}$ \\
\hline Q Pikoli & $\begin{array}{c}22.57 \\
(11.99 ; 42.48)\end{array}$ & $\begin{array}{c}22.63 \\
(12.01 ; 42.64)\end{array}$ & $\begin{array}{c}0.32 \\
(0.07 ; 1.41)\end{array}$ & $\begin{array}{c}0.00 \\
(0.00 ; 1.31)\end{array}$ & $\begin{array}{c}0.00 \\
(0.00 ;>33.30)\end{array}$ & $\begin{array}{c}0.00 \\
(0.00 ; 0.49)\end{array}$ & $\begin{array}{c}0.00 \\
(0.00 ; 0.00)\end{array}$ & $\begin{array}{c}20.93 \\
(13.93 ; 31.43)\end{array}$ \\
\hline Q Tyefu & $\begin{array}{c}15.12 \\
(4.51 ; 50.62)\end{array}$ & $\begin{array}{c}17.10 \\
(3.61 ; 81.00)\end{array}$ & $\begin{array}{c}0.00 \\
(0.00 ;>19.40)\end{array}$ & $\begin{array}{c}0.00 \\
(0.00 ;>33.00)\end{array}$ & $\begin{array}{c}0.00 \\
(0.00 ;>33.30)\end{array}$ & $\begin{array}{c}0.00 \\
(0.00 ;>145.20)\end{array}$ & $\begin{array}{c}0.00 \\
(0.00 ; 0.00)\end{array}$ & $\begin{array}{c}18.18 \\
(5.30 ; 62.33)\end{array}$ \\
\hline R Dimbaza & $\begin{array}{c}31.96 \\
(10.49 ; 97.37)\end{array}$ & $\begin{array}{c}36.76 \\
(12.04 ; 112.29)\end{array}$ & $\begin{array}{c}0.00 \\
(0.00 ;>19.40)\end{array}$ & $\begin{array}{c}0.00 \\
(0.00 ; 3.99)\end{array}$ & $\begin{array}{c}0.00 \\
(0.00 ; 0.03)\end{array}$ & $\begin{array}{c}0.00 \\
(0.00 ; 85.50)\end{array}$ & $\begin{array}{c}0.00 \\
(0.00 ; 0.07)\end{array}$ & $\begin{array}{c}36.42 \\
(18.00 ; 73.67)\end{array}$ \\
\hline R Laing & $\begin{array}{c}5.31 \\
(2.82 ; 10.00)\end{array}$ & $\begin{array}{c}5.34 \\
(2.60 ; 10.98)\end{array}$ & $\begin{array}{c}0.00 \\
(0.00 ; 2.81)\end{array}$ & $\begin{array}{c}0.00 \\
(0.00 ; 3.42)\end{array}$ & $\begin{array}{c}0.00 \\
(0.00 ;>33.30)\end{array}$ & $\begin{array}{c}0.00 \\
(0.00 ; 4.95)\end{array}$ & $\begin{array}{c}0.00 \\
(0.00 ; 0.00)\end{array}$ & $\begin{array}{c}5.65 \\
(3.33 ; 9.58)\end{array}$ \\
\hline S Wriggleswade & $\begin{array}{c}3.10 \\
(1.81 ; 5.31)\end{array}$ & $\begin{array}{c}2.13 \\
(1.17 ; 3.86)\end{array}$ & $\begin{array}{c}0.43 \\
(0.20 ; 0.93)\end{array}$ & $\begin{array}{c}0.00 \\
(0.00 ; 0.06)\end{array}$ & $\begin{array}{c}0.00 \\
(0.00 ;>33.30)\end{array}$ & $\begin{array}{c}1.54 \\
(0.98 ; 2.43)\end{array}$ & $\begin{array}{c}0.00 \\
(0.00 ; 0.03)\end{array}$ & $\begin{array}{c}0.00 \\
(0.00 ; 0.84)\end{array}$ \\
\hline S Xonxa & $\begin{array}{c}6.00 \\
(3.57 ; 10.08)\end{array}$ & $\begin{array}{c}4.76 \\
(2.61 ; 8.71)\end{array}$ & $\begin{array}{c}0.57 \\
(0.23 ; 1.41)\end{array}$ & $\begin{array}{c}0.87 \\
(0.33 ; 2.26)\end{array}$ & $\begin{array}{c}0.00 \\
(0.00 ;>33.30)\end{array}$ & $\begin{array}{c}4.19 \\
(2.61 ; 6.73)\end{array}$ & $\begin{array}{c}0.00 \\
(0.00 ; 0.00)\end{array}$ & $\begin{array}{c}0.00 \\
(0.00 ; 2.04)\end{array}$ \\
\hline T Umtata & $\begin{array}{c}0.94 \\
(0.41 ; 2.18)\end{array}$ & $\begin{array}{c}0.00 \\
(0.00 ; 0.02)\end{array}$ & $\begin{array}{c}0.69 \\
(0.14 ; 3.32)\end{array}$ & $\begin{array}{c}0.00 \\
(0.00 ; 17.52)\end{array}$ & $\begin{array}{c}0.00 \\
(0.00 ;>33.30)\end{array}$ & $\begin{array}{c}0.00 \\
(0.00 ; 47.10)\end{array}$ & $\begin{array}{c}0.00 \\
(0.00 ; 0.34)\end{array}$ & $\begin{array}{c}0.00 \\
(0.00 ;>95.00)\end{array}$ \\
\hline W Pongolapoort & $\begin{array}{c}0.1 \\
(0.05 ; 0.19) \\
\end{array}$ & $\begin{array}{c}0.00 \\
(0.00 ; 0.00)\end{array}$ & $\begin{array}{c}0.00 \\
(0.00 ; 0.60)\end{array}$ & $\begin{array}{c}0.00 \\
(0.00 ; 0.12)\end{array}$ & $\begin{array}{c}0.00 \\
(0.00 ; 0.11)\end{array}$ & $\begin{array}{c}0.00 \\
(0.00 ; 0.11)\end{array}$ & $\begin{array}{c}0.00 \\
(0.00 ; 0.00)\end{array}$ & $\begin{array}{c}0.00 \\
(0.00 ;>95.00)\end{array}$ \\
\hline
\end{tabular}

Table A2. Factor loadings and proportion of variance explained of a principal component analysis (PCA) of four climatic variables spatially associated with 442 dams across South Africa

\begin{tabular}{|c|c|c|c|c|}
\hline & Component 1 & Component 2 & Component 3 & Component 4 \\
\hline Annual mean temperature $\left({ }^{\circ} \mathrm{C}\right)$ & 0.683 & 0.247 & & 0.686 \\
\hline Minimum temperature of coldest month $\left({ }^{\circ} \mathrm{C}\right)$ & 0.602 & -0.322 & 0.513 & -0.520 \\
\hline Maximum temperature of warmest month $\left({ }^{\circ} \mathrm{C}\right)$ & 0.287 & 0.699 & -0.414 & -0.508 \\
\hline Annual precipitation (mm) & 0.297 & -0.589 & -0.751 & \\
\hline Proportion of variance & 0.483 & 0.383 & 0.132 & 0.002 \\
\hline Cumulative proportion & 0.483 & 0.866 & 0.998 & 1.000 \\
\hline
\end{tabular}

Table A3. Factor loadings and proportion of explained variance of a PCA of variation among 442 dams (in a $5 \mathrm{~km}$ wide buffer zone around each dam) in percentage cover of protected area, natural (untransformed) land, commercial and subsistence cultivation, and formal and rural build-up, and road density as length per unit area

\begin{tabular}{|c|c|c|c|c|c|c|c|}
\hline & Component 1 & Component 2 & Component 3 & Component 4 & Component 5 & Component 6 & Component 7 \\
\hline Protected area (\%) & 0.314 & 0.134 & 0.321 & 0.838 & 0.249 & 0.110 & \\
\hline Natural (\%) & 0.493 & & 0.258 & -0.450 & 0.357 & 0.527 & -0.274 \\
\hline Commercial cultivation (\%) & -0.303 & 0.285 & -0.649 & 0.203 & 0.372 & 0.274 & -0.389 \\
\hline Subsistence cultivation (\%) & & -0.667 & & & 0.620 & -0.389 & -0.130 \\
\hline Formal urban build-up (\%) & -0.489 & & 0.573 & & & & -0.645 \\
\hline Rural build-up (\%) & & -0.666 & -0.115 & 0.215 & -0.395 & 0.566 & -0.142 \\
\hline Road density $\left(\mathrm{km} \cdot \mathrm{km}^{-2}\right)$ & -0.572 & & 0.257 & & 0.355 & 0.397 & 0.561 \\
\hline Proportion of variance & 0.302 & 0.224 & 0.167 & 0.122 & 0.083 & 0.068 & 0.034 \\
\hline Cumulative proportion & 0.302 & 0.527 & 0.693 & 0.816 & 0.898 & 0.966 & 1.000 \\
\hline
\end{tabular}


Table A4. Human-related land cover within a $5 \mathrm{~km}$ buffer zone around dams were compared to the land cover in the primary catchment areas (river basins). Number of dams ( $n$ ) and percentage coverage of four land use types in each catchment are shown, together with the corresponding mean and standard deviation (SD) of percentage land cover around dams, and the Holm-corrected $p$ values adjusted for multiple Wilcoxon rank sum tests. Where fewer than 5 non-zero values were available, 'n.a.' indicates that the rank sum test was not applied.

\begin{tabular}{|c|c|c|c|c|c|c|c|c|c|c|c|c|c|}
\hline \multirow[t]{2}{*}{ Basin } & \multirow[t]{2}{*}{$n$} & \multicolumn{3}{|c|}{ Commercial cultivation } & \multicolumn{3}{|c|}{ Subsistence cultivation } & \multicolumn{3}{|c|}{ Formal urban build-up } & \multicolumn{3}{|c|}{ Rural build-up } \\
\hline & & Whole & Mean \pm SD & $p$ & Whole & Mean \pm SD & $P$ & Whole & Mean \pm SD & $p$ & Whole & Mean \pm SD & $P$ \\
\hline A & 48 & 6.19 & $5.65 \pm 5.63$ & $<0.0001$ & 2.33 & $2.10 \pm 4.73$ & $<0.0001$ & 0.86 & $1.38 \pm 3.44$ & $<0.0001$ & 2.13 & $3.62 \pm 7.04$ & $<0.0001$ \\
\hline B & 42 & 12.67 & $12.06 \pm 13.70$ & $<0.0001$ & 2.98 & $1.34 \pm 2.99$ & $<0.0001$ & 0.25 & $0.88 \pm 2.08$ & $<0.0001$ & 3.39 & $2.26 \pm 3.97$ & $<0.0001$ \\
\hline C & 68 & 28.73 & $25.05 \pm 19.56$ & $<0.0001$ & 0.35 & $0.55 \pm 2.42$ & $<0.0001$ & 0.53 & $5.05 \pm 10.19$ & $<0.0001$ & 0.14 & $0.23 \pm 1.18$ & $<0.0001$ \\
\hline$D$ & 56 & 2.44 & $8.14 \pm 14.57$ & $<0.0001$ & 0.40 & $1.24 \pm 5.58$ & n.a. & 0.03 & $0.39 \pm 1.55$ & $<0.0001$ & 0.19 & $0.29 \pm 1.42$ & n.a. \\
\hline$E$ & 7 & 4.11 & $16.02 \pm 13.91$ & 0.0414 & 0.01 & $0.00 \pm 0.00$ & n.a. & 0.02 & $0.26 \pm 0.53$ & n.a. & 0.00 & $0.00 \pm 0.00$ & n.a. \\
\hline G & 32 & 41.76 & $13.46 \pm 16.98$ & $<0.0001$ & 0.00 & $0.00 \pm 0.00$ & n.a. & 2.04 & $5.55 \pm 8.37$ & $<0.0001$ & 0.00 & $0.00 \pm 0.00$ & n.a. \\
\hline $\mathrm{H}$ & 18 & 30.58 & $13.03 \pm 8.22$ & 0.0001 & 0.00 & $0.00 \pm 0.00$ & n.a. & 0.29 & $0.66 \pm 1.22$ & 0.0007 & 0.00 & $0.00 \pm 0.00$ & n.a. \\
\hline$J$ & 14 & 3.72 & $1.79 \pm 2.23$ & 0.0013 & 0.00 & $0.00 \pm 0.00$ & n.a. & 0.04 & $0.29 \pm 0.61$ & n.a. & 0.00 & $0.00 \pm 0.00$ & n.a. \\
\hline K & 17 & 15.15 & $12.44 \pm 14.37$ & 0.0002 & 0.02 & $0.002 \pm 0.01$ & n.a. & 1.24 & $3.11 \pm 3.29$ & 0.0013 & 0.28 & $0.00 \pm 0.00$ & n.a. \\
\hline $\mathrm{L}$ & 10 & 1.36 & $1.79 \pm 2.61$ & 0.0294 & 0.00 & $0.00 \pm 0.00$ & n.a. & 0.03 & $0.002 \pm 0.01$ & n.a. & 0.05 & $0.02 \pm 0.05$ & n.a. \\
\hline M & 4 & 4.46 & $5.07 \pm 4.48$ & n.a. & 0.00 & $0.00 \pm 0.00$ & n.a. & 5.69 & $0.02 \pm 0.03$ & n.a. & 0.01 & $0.00 \pm 0.00$ & n.a. \\
\hline$N$ & 11 & 2.80 & $3.23 \pm 1.95$ & 0.0294 & 0.00 & $0.00 \pm 0.00$ & n.a. & 0.05 & $0.18 \pm 0.60$ & n.a. & 0.01 & $0.00 \pm 0.00$ & n.a. \\
\hline$P$ & 6 & 14.54 & $5.03 \pm 5.60$ & 0.0414 & 0.08 & $0.00 \pm 0.00$ & n.a. & 0.35 & $0.05 \pm 0.11$ & n.a. & 0.07 & $0.03 \pm 0.04$ & n.a. \\
\hline $\mathrm{Q}$ & 11 & 2.46 & $3.29 \pm 1.96$ & 0.0078 & 0.22 & $1.40 \pm 2.05$ & 0.0111 & 0.06 & $0.00 \pm 0.00$ & n.a. & 0.18 & $1.85 \pm 2.69$ & n.a. \\
\hline $\mathrm{R}$ & 9 & 3.16 & $1.46 \pm 2.75$ & n.a. & 7.45 & $10.12 \pm 6.06$ & 0.0111 & 1.15 & $1.89 \pm 3.29$ & n.a. & 4.50 & $7.59 \pm 2.88$ & 0.0177 \\
\hline$S$ & 12 & 2.53 & $2.07 \pm 3.40$ & 0.0137 & 7.04 & $11.27 \pm 9.71$ & 0.0029 & 0.13 & $0.64 \pm 1.49$ & n.a. & 3.88 & $5.63 \pm 5.22$ & 0.0076 \\
\hline $\mathrm{T}$ & 8 & 4.49 & $2.85 \pm 5.02$ & 0.0414 & 12.99 & $10.85 \pm 9.00$ & 0.0111 & 0.20 & $0.26 \pm 0.73$ & n.a. & 9.74 & $10.65 \pm 7.13$ & 0.0177 \\
\hline U & 14 & 16.69 & $18.76 \pm 19.65$ & 0.0013 & 2.59 & $2.02 \pm 2.33$ & 0.0055 & 2.71 & $2.17 \pm 2.19$ & 0.0033 & 9.78 & $16.43 \pm 14.11$ & 0.0065 \\
\hline V & 10 & 8.57 & $15.57 \pm 9.26$ & 0.0137 & 5.05 & $2.88 \pm 3.81$ & 0.0078 & 0.35 & $2.00 \pm 4.52$ & 0.0059 & 4.56 & $2.88 \pm 3.79$ & 0.0177 \\
\hline W & 33 & 5.38 & $12.11 \pm 12.49$ & $<0.0001$ & 6.42 & $1.34 \pm 3.41$ & $<0.0001$ & 0.19 & $1.34 \pm 2.10$ & $<0.0001$ & 6.11 & $4.85 \pm 5.35$ & $<0.0001$ \\
\hline$x$ & 12 & 7.10 & $10.04 \pm 9.61$ & 0.0044 & 1.10 & $0.79 \pm 2.60$ & n.a. & 0.29 & $0.42 \pm 0.84$ & 0.0044 & 2.50 & $1.80 \pm 3.93$ & 0.0088 \\
\hline
\end{tabular}

